\title{
Jordan: Fifth Post-Program Monitoring Discussions-Staff Report; and Press Release on the Executive Board Consideration
}

In the context of the post-program monitoring discussions with Jordan, the following documents have been released and are included in this package:

- The staff report and informational annex for the Fifth Post-Program Monitoring Discussions, prepared by a staff team of the IMF, following discussions that ended on April 30, 2007, with the officials of Jordan on economic developments and policies. Based on information available at the time of these discussions, the staff report was completed on June 8, 2007. The views expressed in the staff report are those of the staff team and do not necessarily reflect the views of the Executive Board of the IMF.

- $\quad$ A Press Release summarizing the views of the Executive Board consideration of the staff report.

The policy of publication of staff reports and other documents allows for the deletion of market-sensitive information.

To assist the IMF in evaluating the publication policy, reader comments are invited and may be sent by e-mail to publicationpolicy@imf.org.

Copies of this report are available to the public from

International Monetary Fund • Publication Services

$70019^{\text {th }}$ Street, N.W. • Washington, D.C. 20431

Telephone: (202) 623-7430 • Telefax: (202) 623-7201

E-mail: publications@imf.org • Internet: http://www.imf.org

Price: $\$ 18.00$ a copy

\section{International Monetary Fund Washington, D.C.}





\title{
INTERNATIONAL MONETARY FUND
}

\section{JORDAN}

\author{
Fifth Post-Program Monitoring Discussions \\ Prepared by the Middle East and Central Asia Department \\ (In consultation with other departments) \\ Approved by David Owen and Martin Fetherston
}

June 8, 2007

- Mission dates: April 22-30, 2007.

- Team: Messrs. Chami (head), McGettigan, and Watt, Ms. Sab (all MCD), Ms. Lusinyan (FAD), and Mr. Tadesse (PDR).

- Counterparts: Prime minister; minister of finance (and deputy prime minister); Governor of the Central Bank of Jordan (CBJ); and high level government officials and banking sector representatives.

- Last Article IV consultation and PPM discussions: Directors' views can be found on http://www.imf.org/external/np/sec/pn/2007/pn0738.htm. At the authorities' request, PPM was extended through end-2007.

- Credit outstanding: SDR 81.8 million or 48 percent of quota at end-April 2007 (Table 1).

- Mission aide mémoire: http://www.imf.org/external/np/ms/2007/043007.htm. 


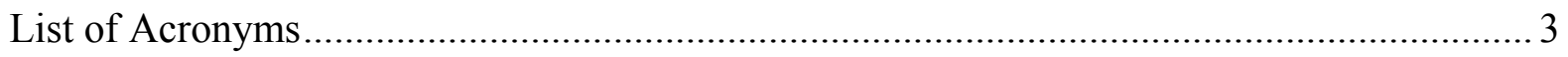

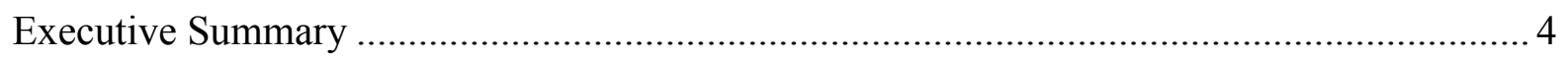

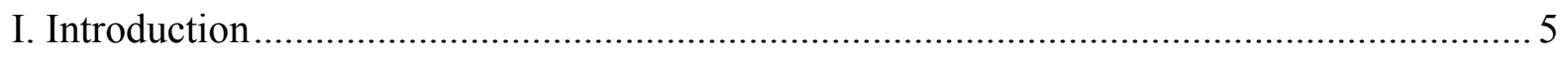

II. Recent Developments and Outlook for 2007 ................................................................... 5

III. Near-Term Economic Outlook and Key Challenges........................................................ 7

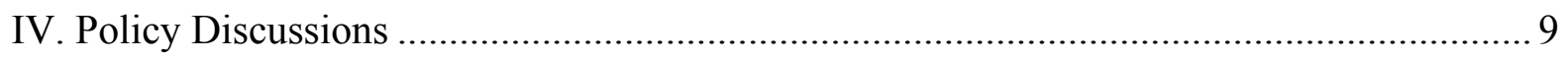

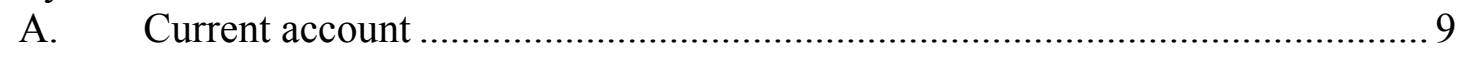

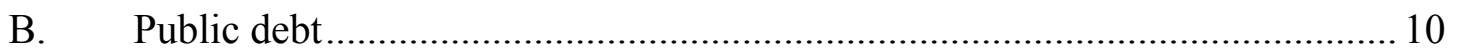

C. Credit growth....................................................................................... 11

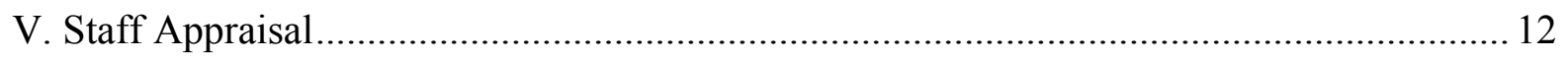

Figures

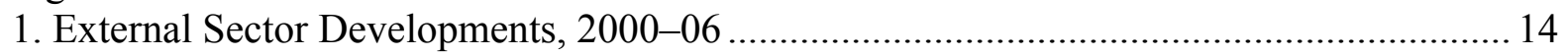

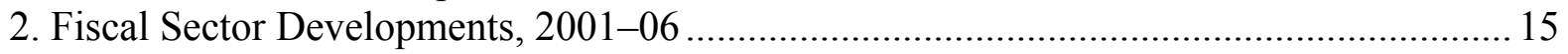

Tables

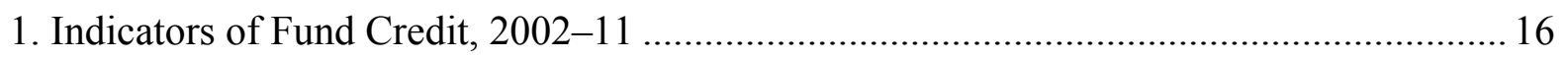

2. Selected Economic Indicators and Macroeconomic Outlook, 2003-12 …........................ 17

3. Indicators of Financial Vulnerability, 2002-06 .......................................................... 18

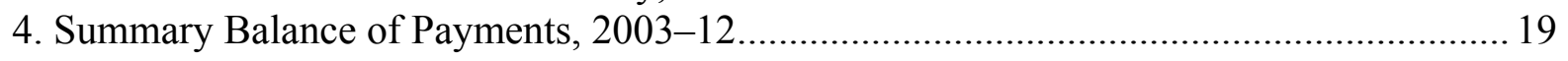

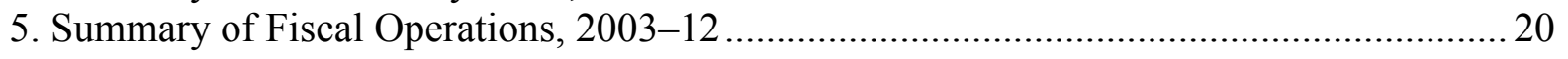

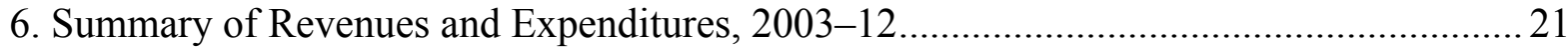

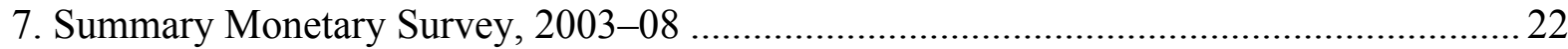

8. Summary Accounts of the Central Bank of Jordan, 2003-08 ………............................... 23

9. Central Government Medium-Term External Debt and Debt Service, 2003-12 ................ 24

Appendixes

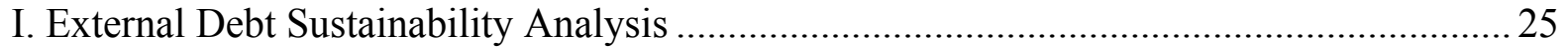

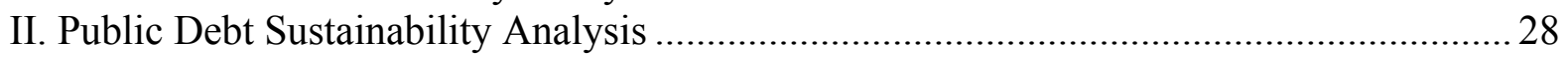




\section{LIST OF ACRONYMS}

$\begin{array}{ll}\text { AML/CFT } & \text { Anti-Money Laundering/Combating Financing of Terrorism } \\ \text { CBJ } & \text { Central Bank of Jordan } \\ \text { CD } & \text { Certificate of Deposit } \\ \text { CPI } & \text { Consumer Price Index } \\ \text { CEE } & \text { Central and Eastern Europe } \\ \text { DOS } & \text { Department of Statistics } \\ \text { DSA } & \text { Debt Sustainability Analysis } \\ \text { EM } & \text { Emerging Market } \\ \text { FDI } & \text { Foreign Direct Investment } \\ \text { FSAP } & \text { Financial Sector Assessment Program } \\ \text { GDP } & \text { Gross Domestic Product } \\ \text { GNFS } & \text { Goods and Nonfactor Services } \\ \text { JD } & \text { Jordanian dinar } \\ \text { MoF } & \text { Ministry of Finance } \\ \text { PFM } & \text { Public Financial Management } \\ \text { PPM } & \text { Post-Program Monitoring } \\ \text { PPP } & \text { Public Private Partnership } \\ \text { REER } & \text { Real Effective Exchange Rate } \\ \text { TSA } & \text { Treasury Single Account } \\ \text { WEO } & \text { World Economic Outlook } \\ \text { yoy } & \text { Year-On-Year }\end{array}$




\section{EXECUTIVE SUMMARY}

\section{Background and focus of discussions}

Jordan's economic performance remains strong. Growth is robust, core inflation is contained, the current account deficit is narrowing, reserves are comfortable, and the fiscal situation continues to improve.

Yet challenges remain, on which discussions focused: (i) a large current account deficit, (ii) stillhigh public debt, and (iii) rapid credit growth.

- Current account: With supportive policies, the current account deficit should decline steadily over the medium term, and the external debt burden should be cut by half by 2012 . Foreign direct investment (FDI) inflows are expected to provide medium-term financing support.

- Public debt: Medium-term fiscal adjustment will reduce the debt-to-GDP ratio to well below the official 60 percent of GDP target by 2011. Given higher medium-term financing requirements, the authorities are considering new debt instruments (sukuk, regional local-currency denominated bonds).

- Credit growth: While banking sector indicators are strong, the effects of past rapid credit growth require careful monitoring.

\section{Staff views and recommendations}

- Adhere to the $\mathbf{2 0 0 7}$ fiscal target and aim for more ambitious medium-term fiscal adjustment. This will help reduce public debt, inflation, and the current account deficit. Given risks, including from higher-than-budgeted fuel subsidies, contingency measures should be implemented if the 2007 targets appear in danger.

- Support the Central Bank of Jordan's (CBJ) plans to strengthen further the supervisory and regulatory framework. A Financial Sector Assessment Program (FSAP) update is needed.

- The CBJ's plan to simplify the interest rate structure and remove excess liquidity through the sale of certificates of deposit (CDs) is appropriate. Staff suggested replacing the one-week repo facility with an overnight facility and reducing the repo rate below the discount rate to reflect maturity differences. Collateralized interbank lending and increased CD auction frequency should help strengthen the interbank market.

\section{Authorities' views}

- The authorities consider the outlook for the Jordanian economy as strong, including on growth, inflation, and the current account.

- The debt target remains a key policy anchor and fiscal policies aim to support this target. These include spending cuts, revenue gains (mainly through improved revenue administration), and, if needed, further fuel price increases. Achieving a lower debt-to-GDP ratio than the 60 percent target by 2011 is well within reach.

- Bank supervision and regulation will continue to be strengthened. Stress tests suggest that banks are resilient and the $\mathrm{CBJ}$ is committed to undertaking further steps to ensure the banking system remains sound. 


\section{INTRODUCTION}

1. In the recent Article IV consultation, staff reported on Jordan's strong economic performance in past years and on policies to sustain this performance. The policy framework discussed in the last staff report remains valid: a medium-term public debt target, continuation with a currency peg, and policies to narrow the current account deficit (fiscal consolidation, prudent monetary policy, and measures to improve the business environment).

2. In the context of the present post-program monitoring (PPM) discussion report, the focus will be on three potential medium-term challenges: (i) the large current account deficit; (ii) the still-high public debt ratio; and (iii) rapid credit growth.

\section{RECENT DEVELOPMENTS AND OUTLOOK FOR 2007}

3. Jordan's strong economic performance continues. Growth was $6 \frac{1}{2}$ percent last year, and was evenly spread between domestic and external demand. Average inflation increased to $7 \frac{1}{2}$ percent in January-April (yoy), reflecting mainly fuel and food price increases, but core inflation remains well contained (see charts). Aided by a broad-based import slowdown and strong export growth, the current account deficit narrowed last year to $13 \frac{1}{2}$ percent of GDP. Trade data for early 2007 show import growth slowing further and exports rising by more than 20 percent. With continued strong private capital inflows, reserves rose to US\$6.3 billon at end-April (more than five months of prospective imports).
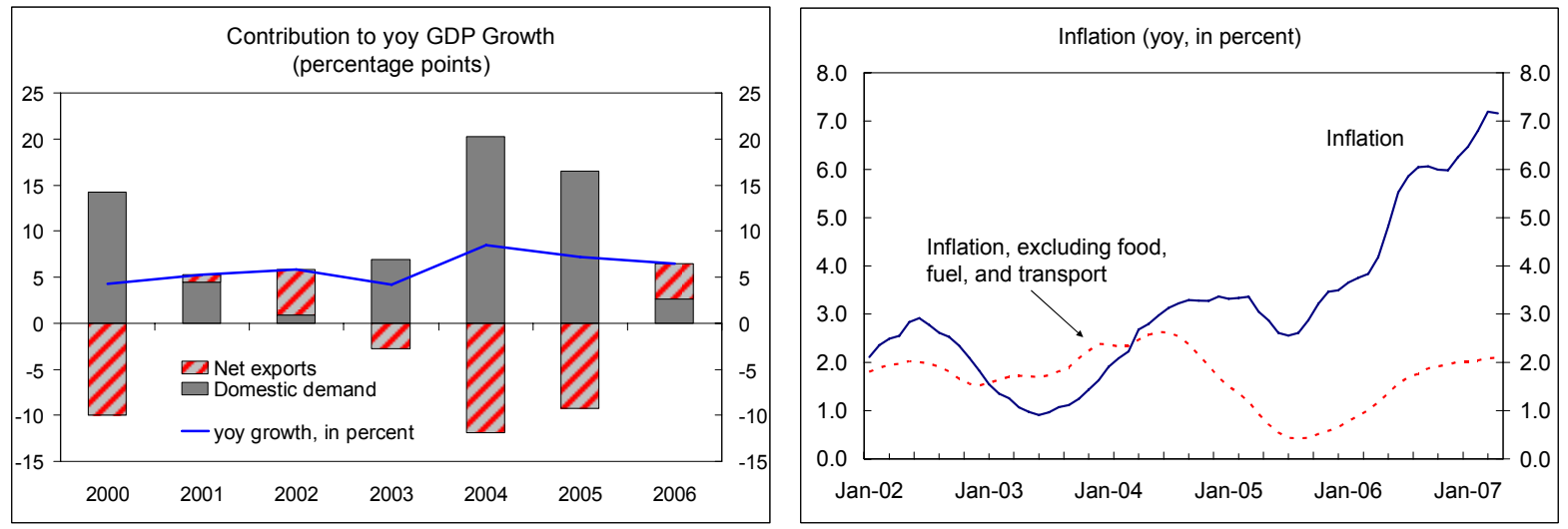

4. The fiscal situation also continues to improve in the face of increased spending pressures. During 2006, strong revenues and fuel price increases more than offset higher spending on transfers (including wage bonuses) and investment. Preliminary estimates suggest that the fiscal deficit (including grants) was about $3 \frac{3}{4}$ percent of GDP last year, compared to 5 percent in 2005, contributing to the fall in the public debt-to-GDP ratio to $72 \frac{1}{2}$ percent at end-2006. In implementing the amended 2007 budget, the authorities are targeting a deficit of $23 / 4$ percent of GDP, as the increase in public sector wages and pensions in the supplementary budget is being offset by nonpriority spending cuts (mainly transfers to 
public sector employees) and additional revenue gains (particularly income tax overperformance). ${ }^{1}$ Strong fiscal performance appears to have continued through the first quarter of this year, with an overall surplus of about 1 percent of GDP, in line with normal seasonal patterns.

Jordan: Summary of Fiscal Operations, 2004-07

(In percent of GDP, unless otherwise noted)

\begin{tabular}{|c|c|c|c|c|c|}
\hline & 2004 & $\frac{\text { Prel. }}{2005}$ & $\frac{\text { Prel. }}{2006}$ & $\begin{array}{l}\text { udget+ } \\
\text { pplem.1/ } \\
2007\end{array}$ & $\frac{\text { Proj. 2l }}{2007}$ \\
\hline Total revenue and grants & 36.7 & 33.0 & 34.2 & 34.6 & 34.8 \\
\hline Budgetary revenue & 25.7 & 28.0 & 30.9 & 29.6 & 29.8 \\
\hline Grants & 10.9 & 5.0 & 3.3 & 5.1 & 5.1 \\
\hline Total budgetary expenditure & 37.7 & 39.1 & 38.9 & 38.1 & 37.6 \\
\hline Current expenditure, of which: & 28.8 & 32.6 & 31.5 & 30.0 & 29.6 \\
\hline Fuel subsidy & 3.2 & 5.6 & 2.8 & 0.0 & 0.0 \\
\hline Capital expenditure and net lending & 8.9 & 6.6 & 7.4 & 8.0 & 7.9 \\
\hline Financing (=deficit including grants) & 1.7 & 5.0 & 3.8 & 3.4 & 2.7 \\
\hline Foreign financing (net) & -1.4 & -0.6 & -0.2 & -1.4 & -1.0 \\
\hline Privatization receipts (net) & 0.5 & 0.0 & 4.2 & 3.1 & 3.1 \\
\hline Domestic financing (net) & 2.6 & 5.5 & -0.3 & 1.7 & 0.6 \\
\hline \multicolumn{6}{|l|}{ Memorandum items: } \\
\hline Overall balance excluding grants & -12.7 & -10.0 & -7.1 & -8.5 & -7.8 \\
\hline Primary balance excluding grants & -9.8 & -7.0 & -3.9 & -5.0 & -4.4 \\
\hline Government and guaranteed net debt & 88.5 & 82.8 & 72.5 & 65.7 & 65.7 \\
\hline GDP at market prices (JD millions) & 8,081 & 9,013 & 10,108 & 11,325 & 11,325 \\
\hline
\end{tabular}

Sources: Jordanian authorities; and Fund staff projections.

1/ 2007 budget includes JD 55.2 million (about 0.5 percent of GDP) amortization to IMF.

2/ Staff projections assume identified fiscal measures to be taken to meet the original 2007 budget target, as agreed with the authorities.

\section{Meanwhile, private sector credit grew by almost 25 percent last year, but broad}

\section{money growth was much lower, given}

reductions in credit to government-due to an increase in privatization receipts - and a large contraction in other items net because of bank capital increases. The pace of credit expansion has, however, slowed sharply over the past year due to the past impact of higher CBJ interest rates, tighter supervision, and the stock market correction.

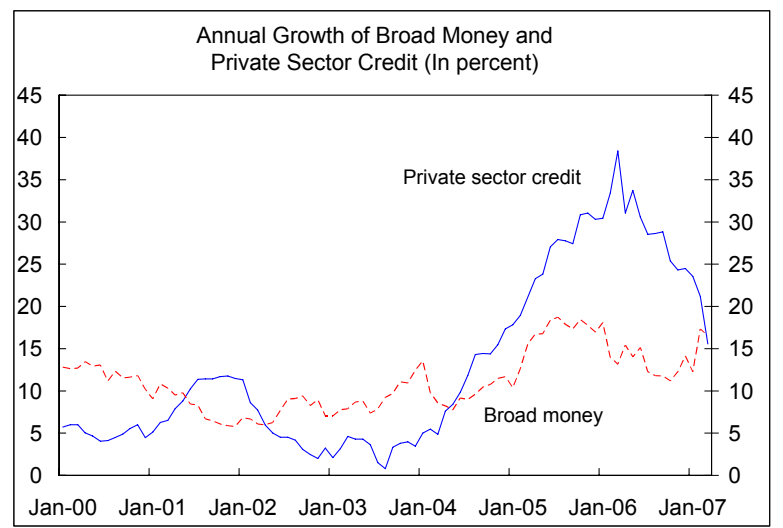

\footnotetext{
${ }^{1}$ The primary fiscal deficit, excluding grants, is expected to widen, marking a modest reduction in fiscal effort in response to the expected increase in grants.
} 


\section{NeAR-Term ECONOMIC OUTLOOK AND Key ChALLENGES}

6. The macroeconomic outlook remains positive (Table 2).

- Average inflation is expected to decline this year to below 6 percent. Given that large fuel price hikes contributed about 2 percentage points to the inflation outturn last year, this appears achievable. Recent double-digit import price increases could, if they persist, make the task more challenging.

- Growth is expected to be about 6 percent, helped by large FDI projects. Liquidity in the region is high, and Jordan continues to be a favored investment destination. Other available indicators, including industrial production, imports, and credit growth, suggest a modest decline in growth from 61/2 percent in 2006.

- A further narrowing of the current account deficit is likely. The strong export momentum of recent years is likely to continue, reflecting strong U.S. and regional demand, a fairly-valued dinar, and large recent investments in traditional export sectors. Import growth is projected to stabilize with falling import unit prices (in line with World Economic Outlook (WEO) forecasts) and import volumes are expected to grow more in line with overall economic activity, following a level jump in recent years on account of FDI, oil prices, and the impact on consumption of the large Iraqi influx (Figure 1).

7. What are the remaining economic challenges?

- A large current account deficit (Tables 3 and 4). Despite the recent narrowing, Jordan's deficit remains one of the highest among emerging market (EM) countries. The deficit is fully financed by FDI and other longterm capital inflows and reserves are at an all-time high. But Jordan could potentially be exposed to sudden shifts in investor sentiment and to regional uncertainties.

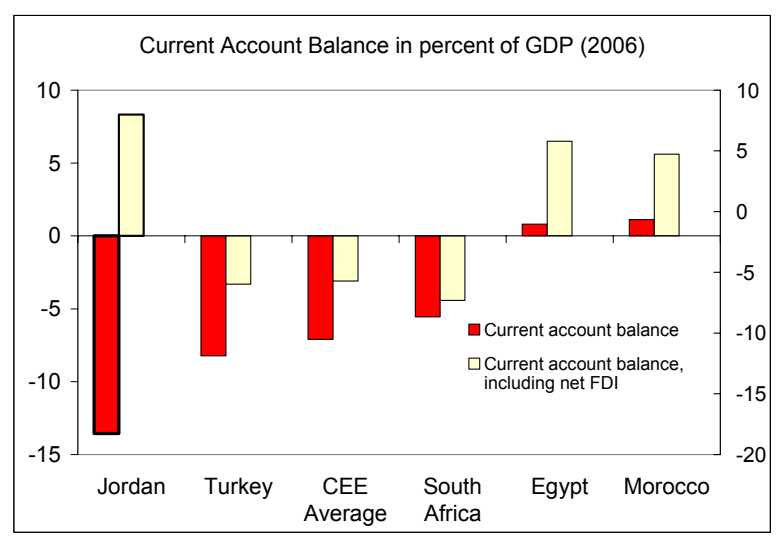


- $\quad$ Still-high public debt (Tables 5 and 6). Jordan has managed to rein in its public debt burden, but, at over 70 percent of GDP, it remains higher than generally considered prudent for EM countries. Jordan also remains reliant on volatile foreign grants. And, as shown by the public debt sustainability analysis (DSA), while Jordan's debt burden is expected to decline sharply even under adverse

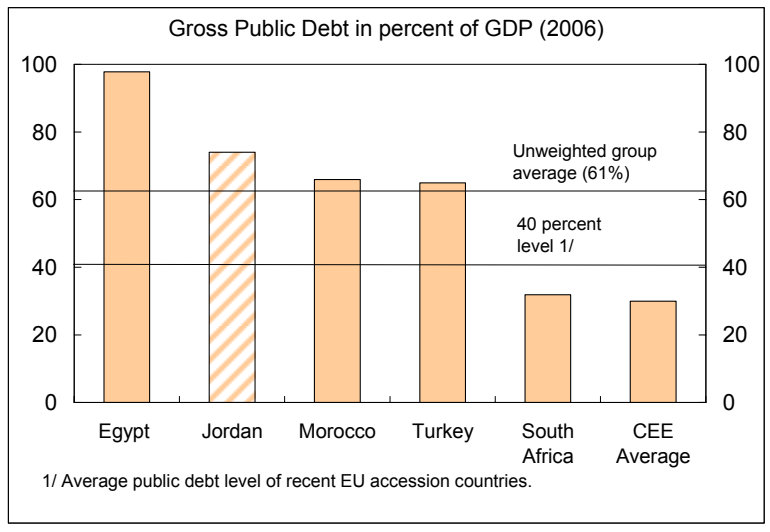
shocks, its profile depends on continued strong fiscal adjustment.

- $\quad$ Credit growth (Tables 7 and 8). While bank prudential indicators are strong and financial sector supervision has strengthened, Jordan's rapid private sector credit growth (until recently), which exceeded that of most peer countries, requires constant monitoring (see chart). Moreover, new forms of lending, carrying greater risks (such as margin and noncollateralized

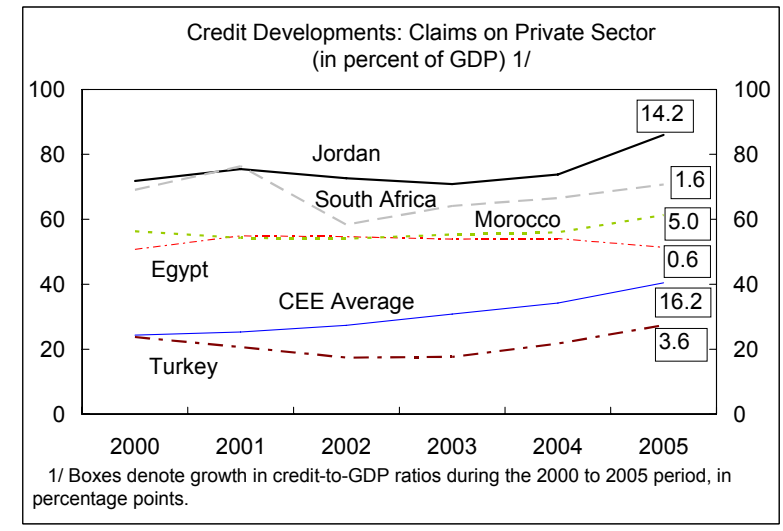
loans) have grown rapidly, although their share remains low.

Jordan: Indicators of Bank Soundness, 2000-06

\begin{tabular}{lrrrrrrr}
\hline & 2000 & 2001 & 2002 & 2003 & 2004 & 2005 & 2006 \\
\hline Capital adequacy ratio & 19.4 & 17.5 & 16.6 & 15.9 & 17.8 & 17.6 & 21.4 \\
Classified loans (in percent of total loans) & 14.6 & 16.0 & 17.1 & 15.5 & 10.3 & 6.6 & 4.3 \\
Provisions (in percent of classified loans) & $\ldots$ & 42.6 & 50.6 & 51.9 & 63.8 & 78.4 & 80.0 \\
Net profits (in percent of total assets) 1/ & 0.3 & 0.7 & 0.6 & 0.7 & 1.1 & 2.0 & 1.7 \\
Net profits (in percent of capital and reserves) 2/ & 4.4 & 10.5 & 9.2 & 10.9 & 13.6 & 21.7 & 18.6 \\
Total assets (JD billions) & 12.4 & 13.6 & 14.6 & 15.2 & 17.4 & 20.6 & 23.8 \\
Share of total assets in foreign currency & 37.0 & 38.2 & 38.6 & 36.0 & 34.8 & 31.4 & 31.7 \\
Share of total liabilities in foreign currency & 35.7 & 36.8 & 37.6 & 34.9 & 34.3 & 31.4 & 31.2 \\
\hline
\end{tabular}

Source: Central Bank of Jordan.

1/ This indicator was 0.5 in Morocco, 0.6 in Egypt and Tunisia, 0.8 in Lebanon, and 3.2 in Kuwait as of end-December 2005. 2/ This indicator was 6.3 in Morocco, 6.9 in Tunisia, 10.7 in Egypt, 11.9 in Lebanon, and 25.7 in Kuwait as of end-December 2005. 


\section{Policy Discussions}

8. The mission focused on the above key challenges. The macroeconomic framework is different from that discussed in the recent Article IV consultation only to the extent that it reflects recent economic developments, including a lower-than-envisaged external current account deficit for 2006, and an amended official budget (although the government plans to stick to the original budget deficit target).

\section{A. Current account}

\section{The authorities were optimistic about Jordan's current account and financing} prospects. Staff agreed that the key sources of last year's current account improvementslower import volume growth, strong export momentum, and high remittance and tourism inflows - are likely to be repeated this year and over the medium term. The financing situation also remains positive, as the large pool of investable funds in the region continues to flow into special economic zones, greenfield projects, and new publicprivate infrastructure initiatives. Strong investment indicators for the first quarter support this view. With respect to the peg, the

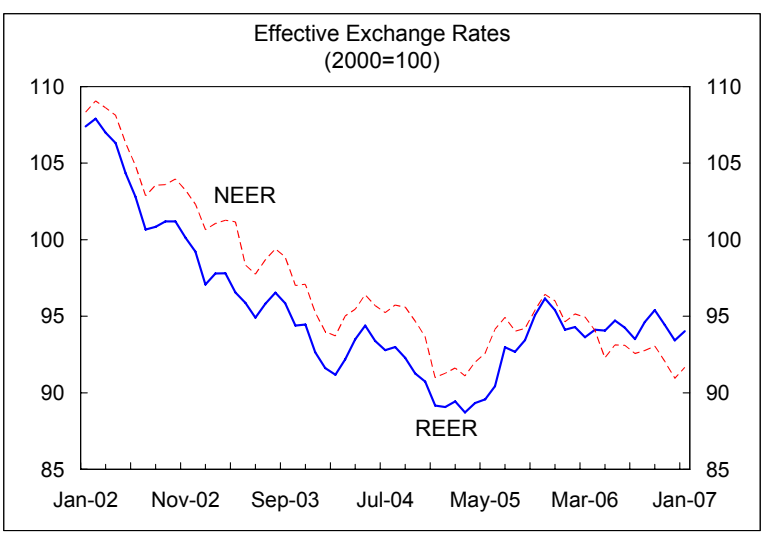
rapid narrowing of the current account deficit, continued large FDI inflows, and surplus foreign exchange conditions in the banking system do not suggest a need to move away from the long-standing fixed exchange rate regime. Indeed, with 2007 inflation expected to be close to that in trading partners and given strong export growth and foreign reserves accumulation, there are currently no indications of an exchange rate misalignment. ${ }^{2}$

10. External debt dynamics also support the picture of underlying strength. With a falling current account deficit and continued strong FDI inflows, reserve ratios to imports and short-term debt should remain comfortable, and external debt could be halved in five years (to 22 percent of GDP). As discussed in the external DSA, these baseline projections are robust to several shocks, but are sensitive to assumptions on private capital inflows (Appendix I). In particular, should FDI flows revert to historical norms, the envisaged decline in external debt would not take place, leaving the economy more exposed to exogenous shocks.

\footnotetext{
${ }^{2}$ See http://www.imf.org/external/pubs/cat/longres.cfm?sk=20604.0 for details (paragraph 17 and Box 1).
} 


\section{B. Public debt}

11. The picture is similarly positive on Jordan's public debt sustainability prospects.

- In the context of the 2007 budget presentation, the authorities announced a new 60 percent of GDP debt ceiling by 2011. They intend to incorporate this in a revised Public Debt Management Law shortly after the November parliamentary elections. Absent severe shocks, the authorities and staff agreed that a more ambitious target could be achieved. (Under staff projections, Jordan's debt burden is set to fall to 52 percent of GDP by end-2011.) However, maintaining the announced target would provide flexibility to deal with shocks (Table 9 and Appendix II).

- The authorities are committed to achieving the original 2007 budget deficit target. Staff cautioned that the fiscal position was subject to risks that include a high budget sensitivity to oil prices (a US\$5-a-barrel price increase adds about 1 percent of GDP to the deficit), possible food subsidy overruns (based on the high first quarter outturn), and likely spending pressures in an election year. Staff suggested that the authorities identify contingency measures, possibly to include cuts in budgeted cash transfers to the private sector and nonpriority current and capital spending, as well as increases as needed in domestic fuel prices. The authorities indicated that they did not intend to implement an automatic adjustment formula at this time, but if the price of oil increased much further, they would raise fuel prices (the budget provides for oilrelated transfers). ${ }^{3}$

- With medium-term domestic financing requirements set to increase-reflecting a winding down of Paris Club rescheduling and privatization - the authorities are planning to expand their set of debt instruments. To this end, they are considering issuing Islamic financing instruments (sukuk) and long-term regional local currency denominated bonds. Staff supported these goals and indicated that, given Jordan's favorable economic conditions and ample regional liquidity, demand for these instruments could be high.

- $\quad$ Discussions are underway between the ministry of finance (MoF) and the CBJ to settle the long-standing issue of government debt to the CBJ. Staff recommended that securitization of government debt to the CBJ take place soon, and that the MoF share its borrowing plans with the CBJ on a quarterly basis, to help the latter's liquidity management.

\footnotetext{
${ }^{3}$ The effective oil import price for Jordan in the first quarter was US $\$ 56 \frac{1}{2}$ a barrel, US $\$ 3 \frac{1}{2}$ a barrel lower than envisaged in the budget.
} 
- Given its potential fiscal importance, the mission also discussed the plans for publicprivate partnership (PPP) projects. ${ }^{4}$ The authorities believe PPPs could generate public savings and harness private expertise and, to that end, they are preparing a legal and institutional framework for PPPs with World Bank assistance. The mission emphasized that the primary focus should be on strengthening public investment planning and creating an appropriate legal and institutional framework, with a strong role for the MoF in safeguarding public finances.

\section{In support of their medium-term public debt targets, the authorities will} continue with structural fiscal reforms. Priorities include tax and expenditure policy, public financial management (PFM), revenue administration, and pension reforms. ${ }^{5}$ While progress in some areas has been good (establishment of a macro-fiscal unit at MoF, improved budget framework for own-budget agencies), other areas have seen delays (Treasury Single Account (TSA), budget processes, and income and sales tax regimes). Staff indicated that the current economic environment lent itself well to these reforms and that further progress was needed on the TSA, budget coverage and classification, and the medium-term expenditure framework.

\section{Credit growth}

\section{While banking sector indicators remain sound, despite last year's major equity} market correction, the authorities intend to monitor the situation closely. Risky loans (margin, noncollateralized, credit card) have grown rapidly, and some banks may not have the capacity to assess associated risks. And bank profitability and other soundness indicators have yet to be tested in an economic downturn. Some small banks are actively seeking market share, with loan-to-deposit ratios increasing to 100 percent in certain cases. The CBJ has strengthened supervision, introduced a prompt corrective action framework, and has enforced a finer classification of credit facilities and stricter provisioning rules since June 2006. Parliament recently passed the Anti-Money Laundering/Combating Financing of Terrorism (AML/CFT) legislation, prepared with World Bank assistance. Looking ahead, the CBJ plans to introduce Basel II-based reporting by fall, to seek improvements in banks' risk management systems, and to introduce shortly new corporate governance guidelines for banks that would aim, among other things, at keeping banking operations at arm's length from owners.

\footnotetext{
${ }^{4}$ A PPP strategy is expected to be launched soon, outlining opportunities for international investors to run ports, utilities, postal services, and public transport, worth US\$6 billion — more than a third of 2007 GDP — over the coming five years, including build-operate-transfer (BOT) type projects.

${ }^{5}$ See http://www.imf.org/external/pubs/cat/longres.cfm?sk=20604.0, paragraph 15, and http://www.imf.org/external/np/ms/2007/043007.htm, paragraph 17.
} 
14. The CBJ indicated that it would continue to absorb excess liquidity through CD issuance. Staff agreed that this would help strengthen the interbank market and help slow domestic credit and import growth. ${ }^{6}$ Staff also suggested that the CBJ increase the frequency of its CD auctions and promote the use of collateralized interbank lending (through the use of a master repo agreement) to help banks better manage their liquidity and limit interbank interest rate volatility.

\section{Staff agreed with the authorities'} plans to simplify the interest rate structure by reducing the interest rate corridor width by 125 basis points. Staff also suggested replacing the seven-day CBJ repo facility with an overnight facility to ensure symmetry with the overnight deposit window. The move took effect early May. Given surplus liquidity, the move did not represent an easing of monetary conditions.
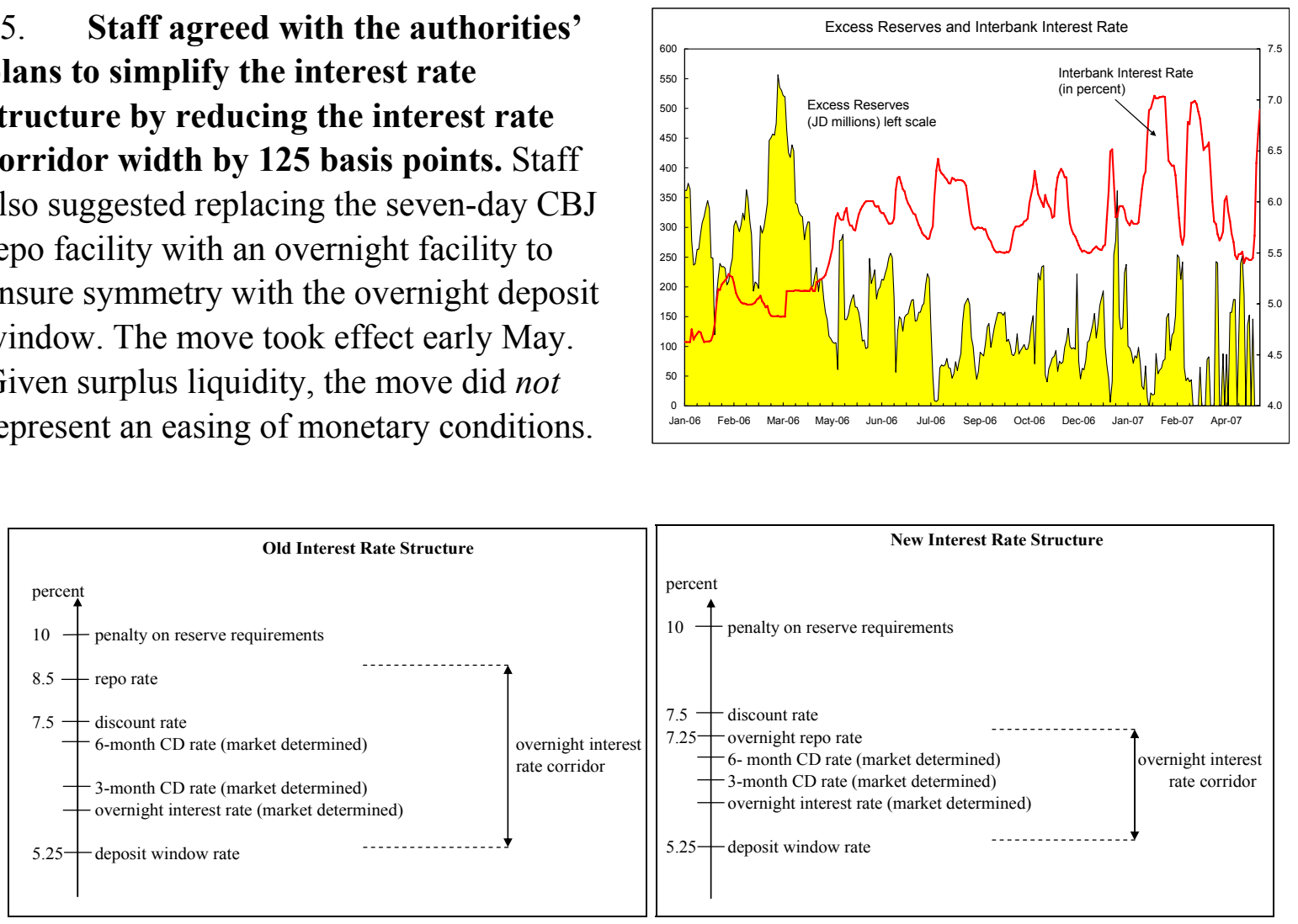

\section{Staff APpraisal}

16. Jordan's macroeconomic outlook is positive, but challenges remain. Barring large negative shocks, growth should remain strong, inflation is expected to decline modestly, the current account deficit will likely narrow further, and public debt should continue to fall. At the same time, external sector imbalances are large, the public debt burden remains high, and rapid private sector credit expansion warrants close monitoring.

\footnotetext{
${ }^{6}$ Staff research suggests that the impact on interest rate levels of bringing excess reserves towards zero should be relatively minor. However, staff estimates also suggest that when excess reserves fall below JD 50 million, the volatility of the spread between the interbank interest rate and the CBJ window rate increases sharply.
} 
17. With supportive policies, the current account deficit should decline steadily over the medium term (to $6 \frac{1}{4}$ percent of GDP by 2012). These policies include sustained fiscal adjustment, prudent monetary policy, and improving the business environment.

18. Fiscal adjustment should aim to reduce the public debt burden to well below the new 60 percent of GDP target by 2011, given remaining risks. In the near term, this should include adopting contingency measures if the 2007 deficit target appears in danger of being breached. Also, given the budget's sensitivity to international fuel price developments, domestic oil prices should be increased to compensate fully for any further increase in world oil prices and a fully automatic price adjustment mechanism instituted as soon as feasible. Over the medium term, most of the adjustment should be on spending. Further support could be given by pressing ahead with the structural reform agenda, against the backdrop of a positive economic environment. Given Jordan's financing requirements, expanding the set of debt instruments to include sukuk and regional local currency-denominated bonds should help widen the investor base, possibly lower borrowing costs, and establish Jordan's presence in international capital markets.

19. The authorities' plans to strengthen further the banking sector supervisory and regulatory framework are appropriate. The CBJ has already taken many steps to improve its oversight of the banks. That said, Jordan's credit growth in recent years stands out from other emerging market countries. And bank soundness indicators have yet to be tested in an economic downturn. Staff therefore looks forward to new corporate governance regulations, improved risk management, and an early FSAP update. Efforts should be made to approve the Credit Bureau legislation soon to help banks better assess credit risk. 
Figure 1. Jordan: External Sector Developments, 2000-06
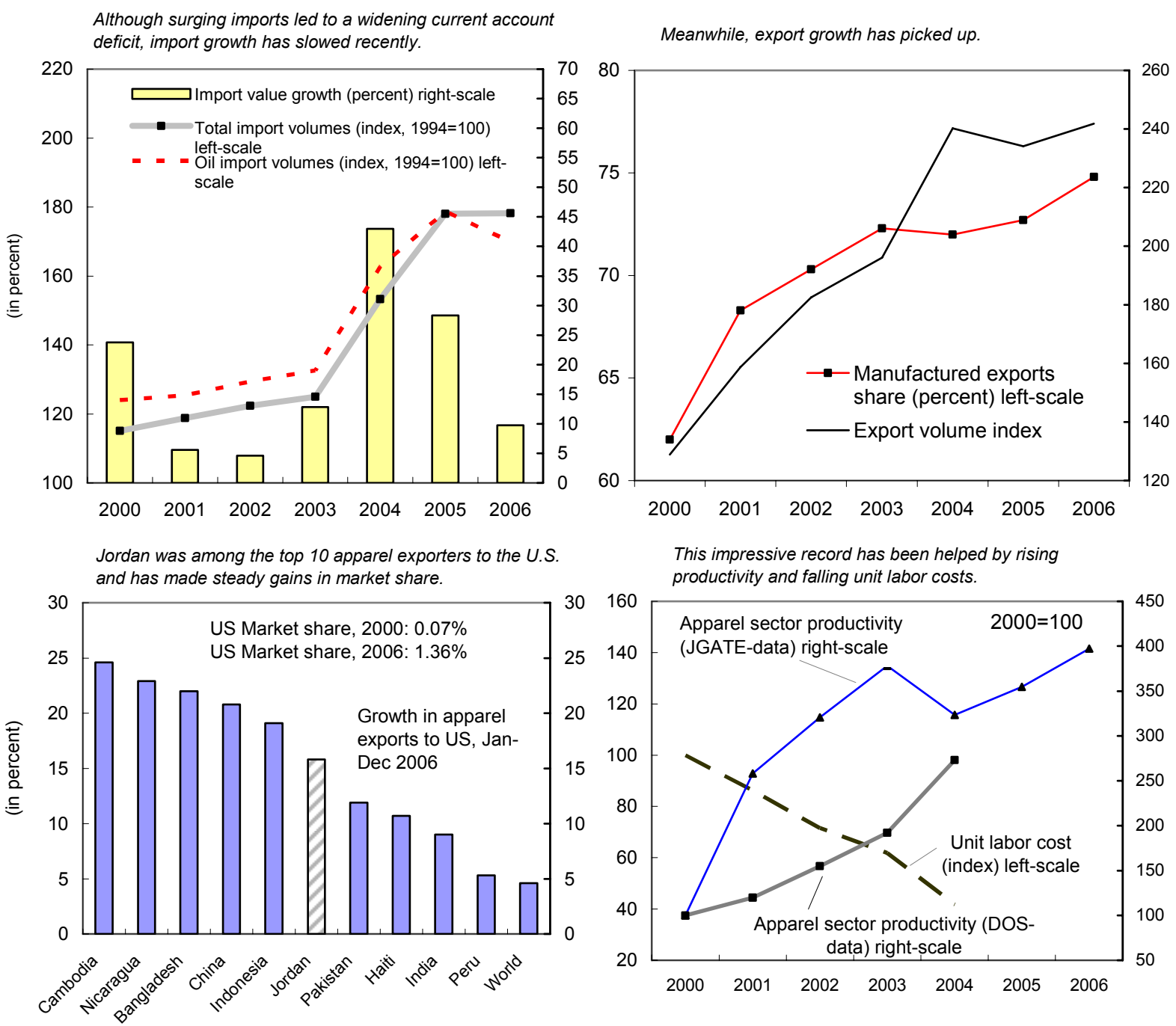

A boom in FDI has been key to financing the current account deficit and boosting reserves.

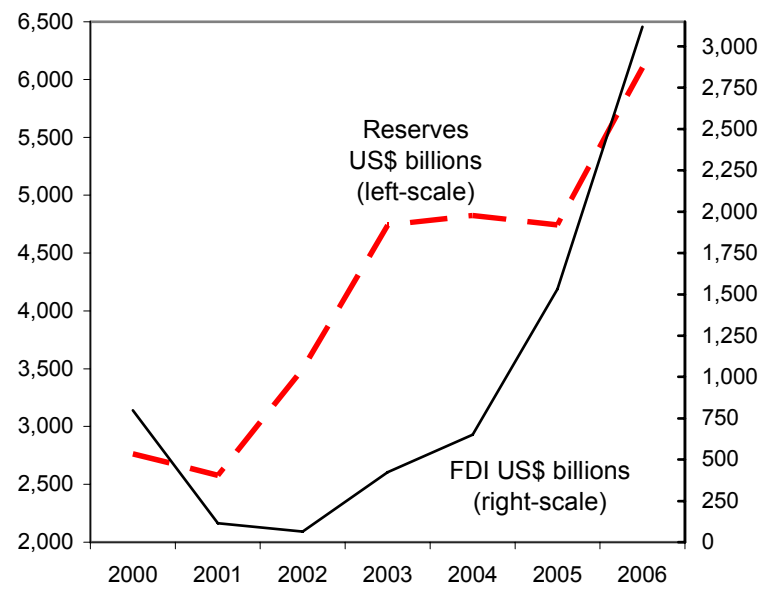

While its contribution to raising private investment bodes well for the medium term.

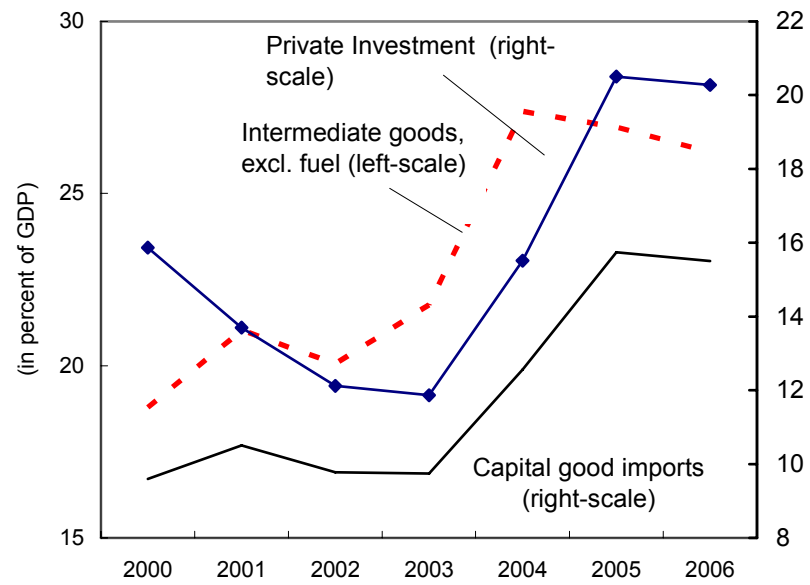

Sources: Jordanian authorities; JGATE; U.S. OTEXA; and Fund staff projections. 
Figure 2. Jordan: Fiscal Sector Developments, 2001-06

(in percent of GDP)
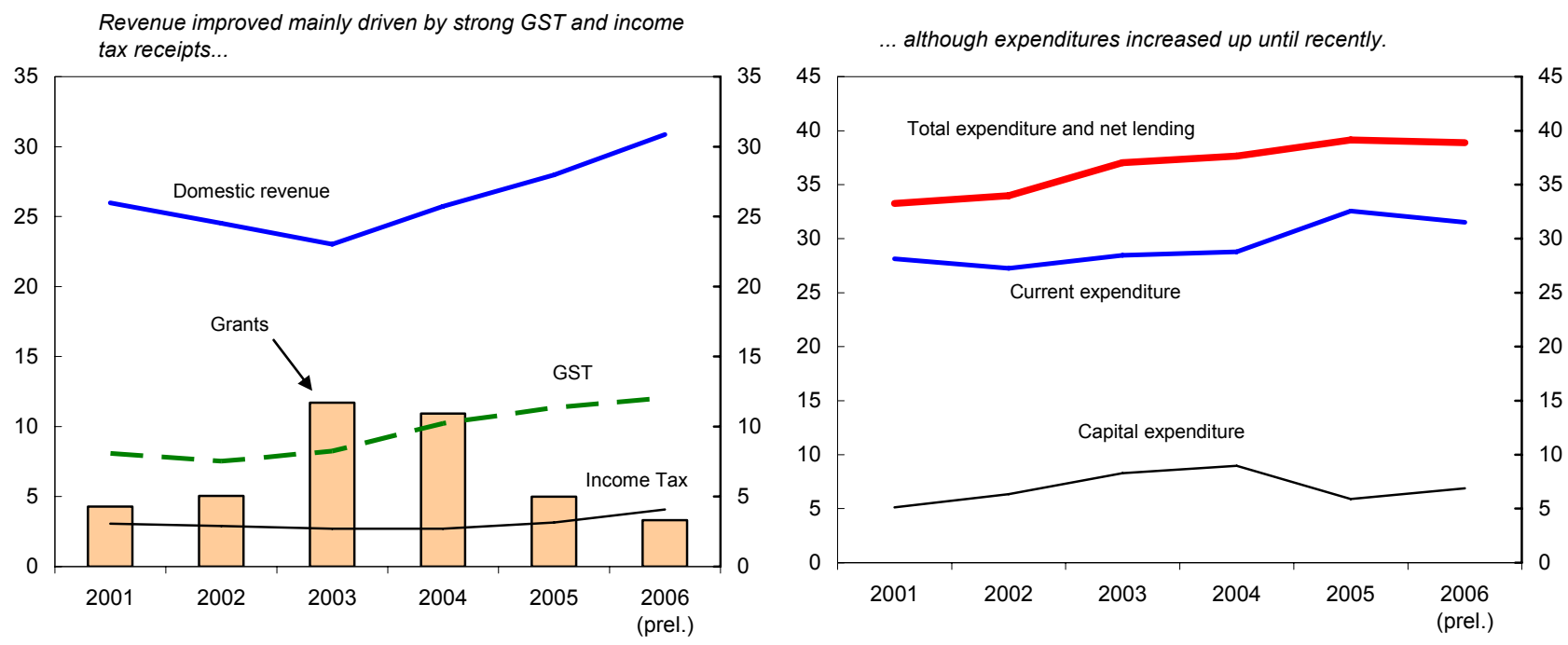

The deficit narrowed recently, and was more than financed by privatization proceeds,...

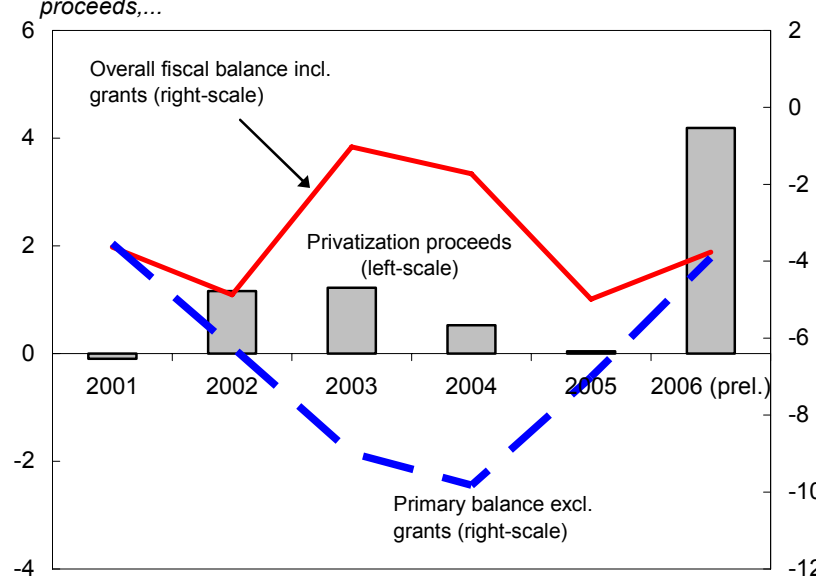

.. helping further reduce external and domestic public debt.

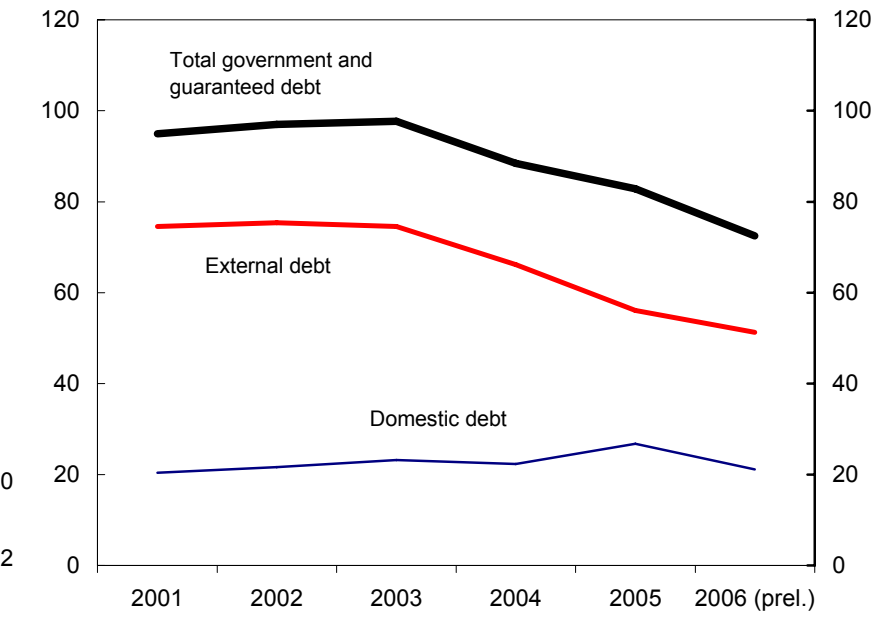

Sources: Jordanian authorities; and Fund staff estimates. 
Table 1. Jordan: Indicators of Fund Credit, 2002-11 (In millions of SDR)

\begin{tabular}{|c|c|c|c|c|c|c|c|c|c|c|}
\hline & \multirow[b]{2}{*}{2002} & \multirow[b]{2}{*}{2003} & \multirow[b]{2}{*}{2004} & \multirow[b]{2}{*}{2005} & \multirow[b]{2}{*}{2006} & \multicolumn{5}{|c|}{ Projections } \\
\hline & & & & & & 2007 & 2008 & 2009 & 2010 & 2011 \\
\hline \multicolumn{11}{|l|}{ Total Fund credit outstanding at end-period } \\
\hline In millions of SDR & 355.0 & 283.6 & 217.5 & 165.3 & 105.2 & 55.4 & 17.9 & 2.5 & 0.0 & 0.0 \\
\hline In millions of U.S. dollars & 475.7 & 416.1 & 335.0 & 236.6 & 158.6 & 83.0 & 26.9 & 3.8 & 0.0 & 0.0 \\
\hline \multicolumn{11}{|l|}{ In percent of: } \\
\hline Quota & 208.2 & 166.3 & 127.5 & 97.0 & 61.7 & 32.5 & 10.5 & 1.5 & 0.0 & 0.0 \\
\hline GDP & 5.0 & 4.1 & 2.9 & 1.9 & 1.1 & 0.5 & 0.2 & 0.0 & 0.0 & 0.0 \\
\hline Exports of goods and nonfactor services & 10.5 & 8.6 & 5.6 & 3.6 & 2.1 & 0.9 & 0.3 & 0.0 & 0.0 & 0.0 \\
\hline Public and publicly guaranteed debt & 6.3 & 5.5 & 4.4 & 3.3 & 2.2 & 1.2 & 0.4 & 0.1 & 0.0 & 0.0 \\
\hline \multicolumn{11}{|l|}{ Transactions under the GRA } \\
\hline Purchases under the GRA & 71.5 & 0.0 & 0.0 & 0.0 & 0.0 & 0.0 & 0.0 & 0.0 & 0.0 & 0.0 \\
\hline Repurchases 1/ & 61.0 & 71.4 & 66.1 & 52.2 & 64.1 & 49.8 & 37.5 & 15.4 & 2.5 & 0.0 \\
\hline Net Purchases & 10.5 & -71.4 & -66.1 & -52.2 & -64.1 & -49.8 & -37.5 & -15.4 & -2.5 & 0.0 \\
\hline Charges and interest $2 /$ & 11.1 & 8.7 & 6.5 & 7.1 & 6.2 & 5.5 & 3.0 & 1.2 & 0.7 & 0.7 \\
\hline \multicolumn{11}{|l|}{ Debt service to the Fund } \\
\hline In millions of SDR & 72.1 & 80.1 & 72.6 & 59.3 & 70.2 & 55.3 & 40.6 & 16.6 & 3.3 & 0.7 \\
\hline In millions of U.S. dollars & 93.7 & 112.2 & 107.5 & 87.6 & 105.3 & 82.7 & 60.8 & 24.9 & 4.9 & 1.0 \\
\hline \multicolumn{11}{|l|}{ In percent of: } \\
\hline Exports of goods and nonfactor services & 2.1 & 2.3 & 1.8 & 1.3 & 1.4 & 0.9 & 0.6 & 0.2 & 0.0 & 0.0 \\
\hline Service on public and publicly guaranteed debt & 11.6 & 13.0 & 12.6 & 10.9 & 12.7 & 10.2 & 7.8 & 3.3 & 0.7 & 0.1 \\
\hline
\end{tabular}

Sources: IMF Finance Department; and Fund staff estimates.

1/ On an expectation basis for purchases made after November 17, 2000.

2/ Includes SDR charges. 
Table 2. Jordan: Selected Economic Indicators and Macroeconomic Outlook, 2003-12

(Quota: SDR 170.5 million)

\begin{tabular}{|c|c|c|c|c|c|c|c|c|c|c|}
\hline & \multirow[b]{2}{*}{2003} & \multirow[b]{2}{*}{2004} & \multirow{2}{*}{$\frac{\text { Prel. }}{2005}$} & \multirow{2}{*}{$\frac{\text { Est. }}{2006}$} & \multicolumn{6}{|c|}{ Projections } \\
\hline & & & & & 2007 & 2008 & 2009 & 2010 & 2011 & 2012 \\
\hline Output and prices & \multicolumn{10}{|c|}{ (Annual percentage changes) } \\
\hline Real GDP at market prices & 4.2 & 8.4 & 7.2 & 6.4 & 6.0 & 6.0 & 6.0 & 6.0 & 6.0 & 6.0 \\
\hline GDP deflator at market prices & 2.1 & 3.1 & 4.0 & 5.4 & 5.7 & 3.9 & 3.2 & 3.0 & 3.0 & 3.0 \\
\hline Nominal GDP at market prices & 6.4 & 11.8 & 11.5 & 12.2 & 12.0 & 10.1 & 9.4 & 9.1 & 9.1 & 9.2 \\
\hline Nominal GDP at market prices (JD millions) & 7,229 & 8,081 & 9,013 & 10,108 & 11,325 & 12,472 & 13,649 & 14,895 & 16,255 & 17,752 \\
\hline Nominal GDP at market prices ( $\$$ millions) & 10,196 & 11,398 & 12,712 & 14,257 & 15,973 & 17,591 & 19,250 & 21,009 & 22,927 & 25,039 \\
\hline Consumer price index (annual average) & 1.6 & 3.4 & 3.5 & 6.3 & 5.7 & 3.9 & 3.2 & 3.0 & 3.0 & 3.0 \\
\hline Consumer price index (end of period) & 2.9 & 3.9 & 4.2 & 7.5 & 4.0 & 3.7 & 3.0 & 3.0 & 3.0 & 3.0 \\
\hline Unemployment rate (percent) & 14.5 & 12.5 & 14.8 & 14.0 & $\ldots$ & $\ldots$ & $\cdots$ & $\ldots$ & $\ldots$ & ... \\
\hline Investment and savings & \multicolumn{10}{|c|}{ (In percent of annual GDP) } \\
\hline Consumption & 99.7 & 102.5 & 113.7 & 108.7 & 106.1 & 106.8 & 105.8 & 104.1 & 102.4 & 100.6 \\
\hline Government & 23.2 & 21.3 & 19.9 & 20.7 & 23.9 & 21.2 & 20.4 & 20.4 & 20.4 & 20.4 \\
\hline Other & 76.5 & 81.1 & 93.8 & 88.0 & 82.2 & 85.6 & 85.4 & 83.7 & 82.0 & 80.2 \\
\hline Gross domestic investment & 20.8 & 27.4 & 27.0 & 27.6 & 28.2 & 26.7 & 25.8 & 25.1 & 24.6 & 24.3 \\
\hline Government & 8.8 & 9.3 & 6.5 & 7.3 & 7.8 & 7.4 & 7.4 & 7.4 & 7.2 & 7.0 \\
\hline Other & 12.1 & 18.1 & 20.5 & 20.3 & 20.4 & 19.3 & 18.3 & 17.7 & 17.4 & 17.2 \\
\hline Gross national savings & 32.4 & 27.4 & 9.2 & 14.1 & 14.8 & 13.5 & 14.1 & 15.6 & 16.7 & 17.9 \\
\hline Government & 7.7 & 7.6 & 1.5 & 3.6 & 5.0 & 5.0 & 5.7 & 5.8 & 5.6 & 5.6 \\
\hline Other & 24.7 & 19.8 & 7.7 & 10.5 & 9.8 & 8.5 & 8.4 & 9.7 & 11.1 & 12.4 \\
\hline Savings-investment balance & 11.6 & 0.0 & -17.8 & -13.6 & -13.4 & -13.2 & -11.7 & -9.5 & -7.9 & -6.3 \\
\hline Government & -1.0 & -1.7 & -5.0 & -3.8 & -2.7 & -2.4 & -1.7 & -1.6 & -1.5 & -1.4 \\
\hline Other & 12.6 & 1.7 & -12.8 & -9.8 & -10.6 & -10.8 & -10.0 & -7.9 & -6.3 & -4.9 \\
\hline \multicolumn{11}{|l|}{ Fiscal operations } \\
\hline Revenue and grants & 34.7 & 36.7 & 33.0 & 34.2 & 34.8 & 32.4 & 32.4 & 32.1 & 31.7 & 31.4 \\
\hline Of which: grants & 11.7 & 10.9 & 5.0 & 3.3 & 5.1 & 2.0 & 1.8 & 1.7 & 1.5 & 1.4 \\
\hline Expenditure and net lending (including off-budget) & 35.8 & 38.4 & 38.0 & 37.9 & 37.6 & 34.8 & 34.1 & 33.7 & 33.2 & 32.8 \\
\hline Overall fiscal balance including grants & -1.0 & -1.7 & -5.0 & -3.8 & -2.7 & -2.4 & -1.7 & -1.6 & -1.5 & -1.4 \\
\hline Overall fiscal balance excluding grants & -12.7 & -12.7 & -10.0 & -7.1 & -7.8 & -4.4 & -3.5 & -3.2 & -3.1 & -2.8 \\
\hline Primary fiscal balance excluding grants & -9.0 & -9.8 & -7.0 & -3.9 & -4.4 & -0.8 & 0.2 & 0.3 & 0.3 & 0.3 \\
\hline Government and government-guaranteed net debt & 97.7 & 88.5 & 82.8 & 72.5 & 65.7 & 61.9 & 58.3 & 54.9 & 51.6 & 48.3 \\
\hline Of which: external debt & 74.5 & 66.2 & 56.1 & 51.3 & 45.1 & 39.3 & 34.4 & 30.0 & 25.9 & 22.2 \\
\hline \multicolumn{11}{|l|}{ External sector } \\
\hline Current account balance (after grants), of which: & 11.6 & 0.0 & -17.8 & -13.6 & -13.4 & -13.2 & -11.7 & -9.5 & -7.9 & -6.3 \\
\hline Exports, f.o.b. ( $\$$ billions) & 3.1 & 3.9 & 4.3 & 5.2 & 6.0 & 6.7 & 7.5 & 8.4 & 9.3 & 10.2 \\
\hline Imports, f.o.b. (\$ billions) & 5.1 & 7.3 & 9.3 & 10.2 & 11.4 & 12.6 & 13.6 & 14.6 & 15.6 & 16.7 \\
\hline Oil and oil products ( $\$$ billions) & 0.8 & 1.4 & 2.2 & 2.4 & 2.4 & 2.7 & 2.8 & 3.0 & 3.1 & 3.3 \\
\hline \multirow[t]{2}{*}{ Private capital inflows (net) } & 6.9 & 6.5 & 19.7 & 26.8 & 17.7 & 14.2 & 12.5 & 10.1 & 8.0 & 7.0 \\
\hline & \multicolumn{10}{|c|}{ (Annual percentage changes) } \\
\hline Merchandise exports, f.o.b. (\$) & 11.2 & 26.0 & 10.8 & 20.8 & 15.5 & 12.3 & 11.8 & 11.3 & 10.5 & 10.5 \\
\hline Merchandise imports, f.o.b. (\$) & 12.8 & 43.0 & 28.3 & 9.8 & 11.5 & 10.5 & 8.3 & 7.0 & 7.0 & 7.0 \\
\hline \multicolumn{11}{|l|}{ Monetary sector } \\
\hline Broad money & 12.4 & 11.7 & 17.0 & 14.1 & 12.0 & 10.1 & 9.4 & 9.1 & 9.1 & 9.2 \\
\hline Net foreign assets & 24.5 & 7.2 & 3.0 & 22.4 & 5.3 & -0.5 & -1.0 & -1.3 & -2.3 & -0.9 \\
\hline Net domestic assets & -0.8 & 17.9 & 34.5 & 6.1 & 19.4 & 20.5 & 17.8 & 16.2 & 15.7 & 14.1 \\
\hline Credit to private sector & 3.5 & 17.3 & 30.3 & 24.5 & 15.6 & 15.0 & 14.1 & 13.4 & 13.4 & 12.6 \\
\hline Stock market index & 53.8 & 62.4 & 92.9 & -32.6 & $\cdots$ & $\ldots$ & $\ldots$ & $\ldots$ & $\ldots$ & ... \\
\hline \multicolumn{11}{|l|}{ Memorandum items: } \\
\hline Gross usable international reserves (\$ millions) $1 /$ & 4,740 & 4,826 & 4,745 & 6,104 & 6,450 & 6,350 & 6,250 & 6,250 & 6,250 & 6,250 \\
\hline In months of prospective imports of GNFS & 6.5 & 5.2 & 4.8 & 5.6 & 5.4 & 4.9 & 4.5 & 4.2 & 3.9 & 3.8 \\
\hline As percent of JD broad money & 46.4 & 43.5 & 35.6 & 40.1 & 37.3 & 33.3 & 29.9 & 27.3 & 24.9 & 22.7 \\
\hline Net international reserves ( $\$$ millions) $1 / 2 /$ & 4,431 & 4,544 & 4,622 & 6,032 & 6,418 & 6,375 & 6,298 & 6,302 & 6,187 & 6,187 \\
\hline Budgetary grants (\$ millions) & 1,193 & 1,246 & 633 & 470 & 810 & 353 & 353 & 353 & 353 & 353 \\
\hline Population (in thousands) & 5,200 & 5,350 & 5,487 & 5,628 & 5,772 & 5,920 & 6,072 & 6,228 & 6,387 & 6,551 \\
\hline Nominal per capita GDP $(\$)$ & 1,961 & 2,131 & 2,317 & 2,533 & 2,767 & 2,971 & 3,170 & 3,373 & 3,589 & 3,822 \\
\hline Real effective exchange rate $(2000=100)$ & 95.8 & 92.1 & 91.9 & 97.3 & $\cdots$ & $\cdots$ & $\ldots$ & $\ldots$ & $\ldots$ & \\
\hline Percent change (+: appreciation) & -7.2 & -3.9 & -0.3 & 6.0 & 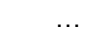 & $\cdots$ & $\ldots$ & $\cdots$ & 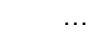 & \\
\hline
\end{tabular}

Sources: Jordanian authorities; and Fund staff estimates and projections.

$1 /$ NIR exceeds gross usable international reserves in years where the net fund position is negative.

2/ Net of short-term foreign liabilities, foreign currency swaps, and commercial bank foreign deposits with the CBJ. 
Table 3. Jordan: Indicators of Financial Vulnerability, 2002-06

(End of period, unless otherwise noted)

\begin{tabular}{|c|c|c|c|c|c|}
\hline & 2002 & 2003 & 2004 & $\frac{\text { Prel. }}{2005}$ & $\frac{\text { Est. }}{2006}$ \\
\hline Monetary and financial indicators & \multicolumn{5}{|c|}{ (In percent of GDP) } \\
\hline Gross domestic currency public debt (including own-budget agencies) & 24.4 & 25.1 & 25.8 & 27.4 & 29.3 \\
\hline Central government net domestic currency borrowing requirement & 2.6 & 4.3 & 2.6 & 5.5 & -0.3 \\
\hline Broad money (annual growth, in percent) & 7.0 & 12.4 & 11.7 & 17.0 & 14.1 \\
\hline Broad domestic currency liquidity (M2) (annual growth, in percent) & 7.0 & 11.9 & 8.6 & 20.1 & 14.1 \\
\hline Private sector credit (annual growth, in percent) & 3.2 & 3.5 & 17.3 & 30.3 & 24.5 \\
\hline \multicolumn{6}{|l|}{ Banking sector indicators } \\
\hline Nonperforming loans (excluding interest in suspense, as percent of loans) 1/ & 17.1 & 15.5 & 10.3 & 6.6 & 4.3 \\
\hline Nonperforming loans (as percent of capital and reserves) 1/ & 85.8 & 73.2 & 46.1 & 28.3 & 15.9 \\
\hline Provisions against nonperforming loans (excluding interest in suspense, as percent of such loans) $1 /$ & 50.6 & 51.9 & 63.8 & 78.4 & 80.0 \\
\hline Risk-weighted capital adequacy ratio (in percent) $1 /$ & 16.6 & 15.9 & 17.8 & 17.6 & 21.4 \\
\hline Construction loans in total private credit to residents (in percent) & 16.7 & 17.2 & 17.4 & 16.4 & 17.4 \\
\hline \multirow[t]{2}{*}{ Credit to private sector (in percent of GDP) } & 65.9 & 61.5 & 72.8 & 85.1 & 94.4 \\
\hline & \multicolumn{5}{|c|}{ (In millions of U.S. dollars) } \\
\hline \multicolumn{6}{|l|}{ Foreign currency and external debt indicators } \\
\hline Gross external public debt (\$ millions) & 7,222 & 7,599 & 7,541 & 7,132 & 7,315 \\
\hline In percent of GDP & 75.4 & 74.5 & 66.2 & 56.1 & 51.3 \\
\hline Short-term external debt ( $\$$ millions) $2 /$ & 519 & 541 & 649 & 550 & 552 \\
\hline Total foreign liabilities of central bank ( $\$$ millions) & 612 & 507 & 392 & 315 & 404 \\
\hline Total foreign liabilities of commercial banks ( $\$$ millions) & 4,718 & 4,379 & 4,892 & 5,234 & 5,946 \\
\hline Commercial banks' net foreign asset position ( $\$$ millions) & 1,619 & 1,801 & 2,163 & 2,329 & 2,803 \\
\hline \multicolumn{6}{|l|}{ Official reserves indicators } \\
\hline Gross usable reserves (\$ millions) 3/ & 3,495 & 4,740 & 4,826 & 4,745 & 6,104 \\
\hline In percent of M2 & 29.4 & 35.5 & 32.4 & 27.2 & 30.7 \\
\hline In percent of short-term external debt by remaining maturity & 674 & 875 & 743 & 862 & 1,106 \\
\hline Net international reserves (\$ millions) 3/ & 3,027 & 4,431 & 4,544 & 4,622 & 6,032 \\
\hline In percent of M2 & 25.5 & 33.2 & 30.5 & 26.5 & 30.3 \\
\hline In percent of short-term external debt & 584 & 818 & 700 & 840 & 1,093 \\
\hline \multicolumn{6}{|l|}{ External current account indicators (annual flows) } \\
\hline Merchandise exports, f.o.b. (\$ millions) & 2,770 & 3,082 & 3,883 & 4,301 & 5,198 \\
\hline Annual changes in percent & 20.7 & 11.2 & 26.0 & 10.8 & 20.8 \\
\hline Merchandise imports, f.o.b. (\$ millions) & 4,501 & 5,078 & 7,261 & 9,317 & 10,226 \\
\hline Annual changes in percent & 4.6 & 12.8 & 43.0 & 28.3 & 9.8 \\
\hline Current account balance including grants ( $\$$ millions) & 538 & 1,179 & -2 & $-2,260$ & $-1,933$ \\
\hline In percent of GDP & 5.6 & 11.6 & 0.0 & -17.8 & -13.6 \\
\hline
\end{tabular}

Sources: Jordanian authorities; Bank for International Settlements; WEO; and Fund staff estimates.

1/ Data for 2006 are as of end-June.

2/ Short-term public debt is defined as nonresident treasury bill holdings and amortization falling due during the year.

$3 /$ Excluding foreign currency deposits held by commercial banks with the central bank. 
Table 4. Jordan: Summary Balance of Payments, 2003-12

(In millions of U.S. dollars, unless otherwise noted)

\begin{tabular}{|c|c|c|c|c|c|c|c|c|c|c|}
\hline & \multirow[b]{2}{*}{2003} & \multirow[b]{2}{*}{2004} & \multirow[b]{2}{*}{2005} & \multirow{2}{*}{$\frac{\text { Prel. }}{2006}$} & \multicolumn{6}{|c|}{ Projections } \\
\hline & & & & & 2007 & 2008 & 2009 & 2010 & 2011 & 2012 \\
\hline Current account & 1,179 & -2 & $-2,260$ & $-1,933$ & $-2,137$ & $-2,320$ & $-2,249$ & $-1,992$ & $-1,805$ & $-1,585$ \\
\hline Trade balance & $-1,996$ & $-3,378$ & $-5,016$ & $-5,028$ & $-5,397$ & $-5,852$ & $-6,105$ & $-6,209$ & $-6,360$ & $-6,484$ \\
\hline Exports f.o.b. & 3,082 & 3,883 & 4,301 & 5,198 & 6,005 & 6,743 & 7,540 & 8,396 & 9,274 & 10,246 \\
\hline Of which: domestic exports, f.o.b. & 2,363 & 3,253 & 3,625 & 4,126 & 4,718 & 5,328 & 5,983 & 6,714 & 7,458 & 8,284 \\
\hline Imports f.o.b. & 5,078 & 7,261 & 9,317 & 10,226 & 11,402 & 12,596 & 13,645 & 14,605 & 15,634 & 16,730 \\
\hline Of which: oil-gas imports, f.o.b. & 797 & 1,372 & 2,151 & 2,421 & 2,427 & 2,675 & 2,828 & 2,962 & 3,114 & 3,296 \\
\hline Services (net) & -149 & -73 & -209 & -212 & -155 & -114 & -62 & 0 & 74 & 161 \\
\hline Of which: travel (net) & 610 & 805 & 855 & 1,017 & 1,184 & 1,323 & 1,477 & 1,649 & 1,839 & 2,050 \\
\hline Income (net) & 118 & 233 & 376 & 518 & 544 & 582 & 600 & 616 & 630 & 639 \\
\hline Of which: investment income (net) & -75 & -7 & 96 & 196 & 190 & 192 & 179 & 161 & 139 & 109 \\
\hline Current transfers (net) & 3,206 & 3,216 & 2,588 & 2,790 & 2,871 & 3,066 & 3,319 & 3,601 & 3,851 & 4,099 \\
\hline Public (net) & 1,405 & 1,325 & 745 & 810 & 650 & 600 & 600 & 600 & 600 & 600 \\
\hline Private (net) & 1,801 & 1,891 & 1,843 & 1,979 & 2,221 & 2,466 & 2,719 & 3,001 & 3,251 & 3,499 \\
\hline Of which: remittances (net) & 1,781 & 1,819 & 1,871 & 2,161 & 2,423 & 2,692 & 2,973 & 3,281 & 3,557 & 3,833 \\
\hline Capital account & -11 & 341 & 2,288 & 3,577 & 2,470 & 2,265 & 2,143 & 1,853 & 1,559 & 1,490 \\
\hline Public sector (net) & -717 & -397 & -220 & -249 & -353 & -231 & -269 & -270 & -271 & -271 \\
\hline Disbursements & 178 & 173 & 253 & 270 & 186 & 224 & 244 & 254 & 264 & 264 \\
\hline Amortization & 894 & 570 & 473 & 519 & 539 & 455 & 513 & 524 & 535 & 535 \\
\hline Private sector (net) & 706 & 738 & 2,508 & 3,826 & 2,823 & 2,495 & 2,412 & 2,123 & 1,830 & 1,761 \\
\hline Direct foreign investment & 424 & 651 & 1,532 & 3,121 & 1,700 & 1,500 & 1,500 & 1,300 & 1,200 & 1,200 \\
\hline Portfolio flows & -468 & -337 & 132 & 46 & 350 & 250 & 200 & 200 & 200 & 200 \\
\hline Other capital plus E \& Os & 750 & 424 & 844 & 659 & 773 & 745 & 712 & 623 & 430 & 361 \\
\hline Overall balance & 1,168 & 338 & 27 & 1,644 & 333 & -55 & -106 & -139 & -246 & -94 \\
\hline Financing & $-1,168$ & -338 & -27 & $-1,644$ & -333 & 55 & 106 & 139 & 246 & 94 \\
\hline Increase in NFA (-) $1 /$ & $-1,424$ & -460 & -168 & $-1,820$ & -484 & 111 & 129 & 143 & 246 & 94 \\
\hline Central bank & $-1,267$ & -91 & 49 & $-1,217$ & -387 & 100 & 100 & 0 & 114 & 0 \\
\hline Commercial banks & -158 & -369 & -217 & -603 & -97 & 11 & 29 & 143 & 132 & 94 \\
\hline IMF, net (expectations basis) & -100 & -98 & -77 & -96 & -74 & -56 & -23 & -4 & 0 & 0 \\
\hline Arab Monetary Fund (net) & -9 & -11 & -9 & 0 & 0 & 0 & 0 & 0 & 0 & 0 \\
\hline Relief from debt operations $2 /$ & 94 & 2 & 9 & 63 & 40 & 0 & 0 & 0 & 0 & 0 \\
\hline Debt rescheduling & 271 & 228 & 218 & 209 & 185 & 0 & 0 & 0 & 0 & 0 \\
\hline \multicolumn{11}{|l|}{ Memorandum items: } \\
\hline Gross usable international reserves & 4,740 & 4,826 & 4,745 & 6,104 & 6,450 & 6,350 & 6,250 & 6,250 & 6,250 & 6,250 \\
\hline In months of prospective imports $3 /$ & 6.5 & 5.2 & 4.8 & 5.6 & 5.4 & 4.9 & 4.5 & 4.2 & 3.9 & 3.9 \\
\hline Merchandise export growth, percent & 11.2 & 26.0 & 10.8 & 20.8 & 15.5 & 12.3 & 11.8 & 11.3 & 10.5 & 10.5 \\
\hline Of which: domestic exports & 7.6 & 37.7 & 11.4 & 13.8 & 14.4 & 12.9 & 12.3 & 12.2 & 11.1 & 11.1 \\
\hline Export of GNFS growth, percent & 6.1 & 23.5 & 11.4 & 15.9 & 14.9 & 11.8 & 11.2 & 10.8 & 10.2 & 10.3 \\
\hline Import growth, percent & 12.8 & 43.0 & 28.3 & 9.8 & 11.5 & 10.5 & 8.3 & 7.0 & 7.0 & 7.0 \\
\hline Of which: excluding oil-gas & 13.0 & 37.5 & 22.1 & 8.8 & 14.7 & 10.5 & 9.0 & 7.6 & 7.5 & 7.3 \\
\hline Import of GNFS growth, percent & 9.1 & 35.0 & 26.1 & 9.0 & 11.3 & 10.1 & 8.2 & 7.2 & 7.2 & 7.2 \\
\hline Import oil price ( $\$$ per barrel) & 23.6 & 34.6 & 51.6 & 61.3 & 57.7 & 61.7 & 61.5 & 61.2 & 60.7 & 60.2 \\
\hline \multicolumn{11}{|l|}{ Current account balance } \\
\hline In percent of GDP & 11.6 & 0.0 & -17.8 & -13.6 & -13.4 & -13.2 & -11.7 & -9.5 & -7.9 & -6.3 \\
\hline Excluding grants & -2.2 & -11.6 & -23.6 & -19.2 & -17.5 & -16.6 & -14.8 & -12.3 & -10.5 & -8.7 \\
\hline Private capital (net, percent of GDP) & 6.9 & 6.5 & 19.7 & 26.8 & 17.7 & 14.2 & 12.5 & 10.1 & 8.0 & 7.0 \\
\hline External government debt & 74.5 & 66.2 & 56.1 & 51.3 & 45.1 & 39.3 & 34.4 & 30.0 & 25.9 & 22.2 \\
\hline GDP (\$ millions) & 10,196 & 11,398 & 12,712 & 14,257 & 15,973 & 17,591 & 19,250 & 21,009 & 22,927 & 25,039 \\
\hline
\end{tabular}

Sources: Jordanian authorities; and Fund staff estimates.

1/ The change in Fund credit outstanding is deducted from the change in NFA from monetary survey.

2/ The difference between the face value of debt reduction and the cost of debt operations.

3/ In months of prospective import of goods and nonfactor services (GNFS) of the following year, excluding imports for re-export purposes. 
Table 5. Jordan: Summary of Fiscal Operations, 2003-12

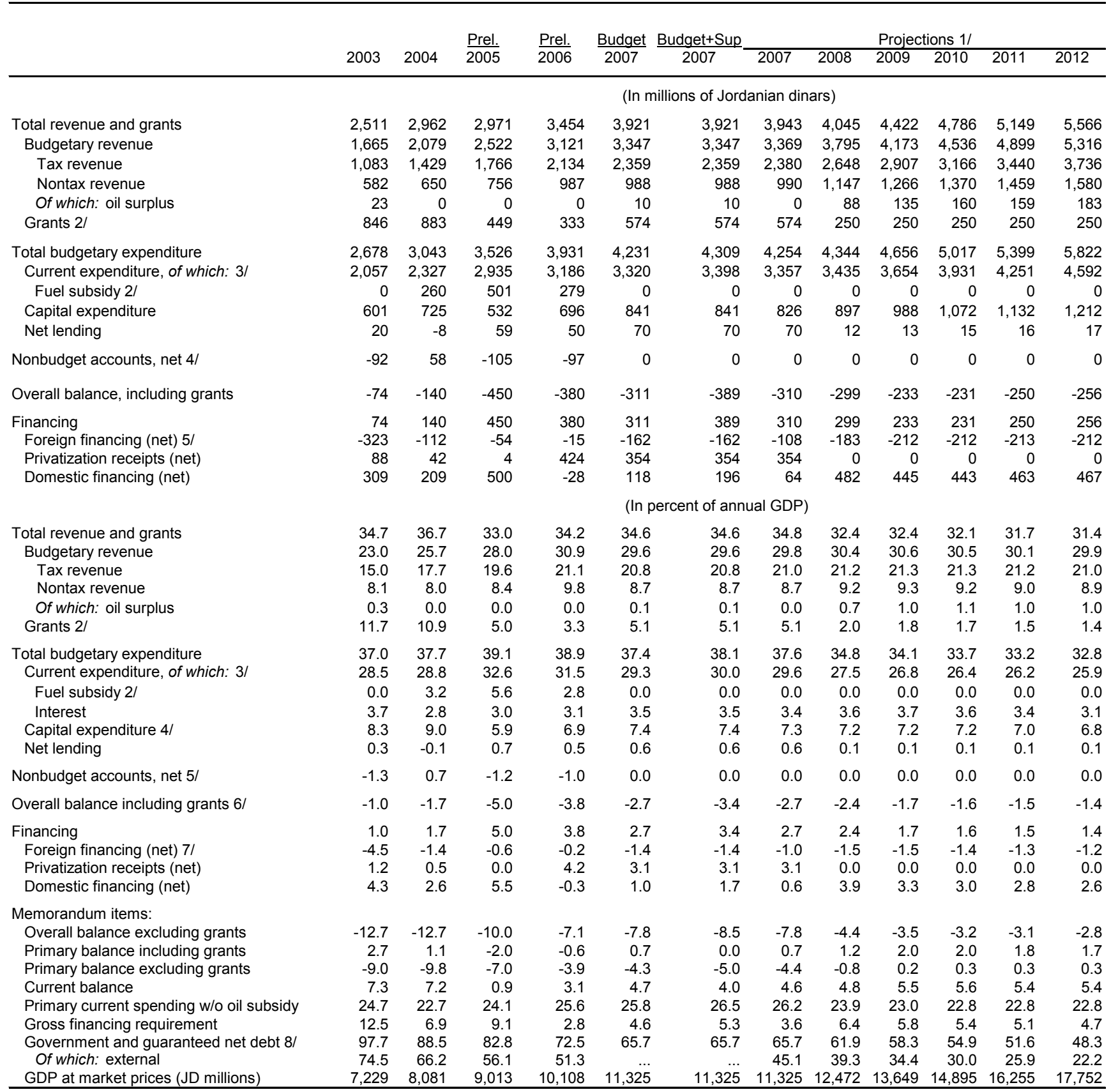

Sources: Jordanian authorities; and Fund staff projections.

$1 /$ Staff projections are in line with the policy framework agreed with the authorities.

2/ Until 2003, the authorities recorded oil grants net of the fuel subsidy, whereas starting in 2004 the fuel subsidy is shown as expenditure and

oil grants are calculated at market prices. Starting in 2007, revenue from petroleum products is shown as oil surplus in the nontax revenue.

3/ 2005 data include JD 58.5 million of spending carried out in 2004 but paid in 2005.

4/ Includes some current expenditure, such as maintenance and wage-related spending.

$5 /$ Includes discrepancy and spending out of privatization proceeds. In 2003, includes spending on building up the strategic oil reserve.

6/ The projected 2007 deficit is about 1.1 percentage points of GDP higher than in the previous staff report (EBS/07/17) mainly reflecting a downward revision in the revenue from oil surplus (1 percent of GDP) as a result of recent international oil price increases.

7/ The 2007 budget includes JD 55.2 million (about 0.5 percent of GDP) amortization to IMF.

8/ Domestic debt is net of government deposits with the banking system. 
Table 6. Jordan: Summary of Revenues and Expenditures, 2003-12

\begin{tabular}{|c|c|c|c|c|c|c|c|c|c|c|c|c|}
\hline & & & Prel & Prel. & Budget & Budget+Sup & \multicolumn{6}{|c|}{ Projections 1/ } \\
\hline & 2003 & 2004 & $\overline{2005}$ & 2006 & 2007 & 2007 & 2007 & 2008 & 2009 & 2010 & 2011 & 2012 \\
\hline & \multicolumn{12}{|c|}{ (In millions of Jordanian dinars) } \\
\hline Total revenue and grants & 2,511 & 2,962 & 2,971 & 3,454 & 3,921 & 3,921 & 3,943 & 4,045 & 4,422 & 4,786 & 5,149 & 5,566 \\
\hline Domestic revenue & 1,665 & 2,079 & 2,522 & 3,121 & 3,347 & 3,347 & 3,369 & 3,795 & 4,173 & 4,536 & 4,899 & 5,316 \\
\hline Tax revenue, of which: & 1,083 & 1,429 & 1,766 & 2,134 & 2,359 & 2,359 & 2,380 & 2,648 & 2,907 & 3,166 & 3,440 & 3,736 \\
\hline Taxes on income and profits & 195 & 218 & 284 & 411 & 470 & 470 & 490 & 548 & 604 & 660 & 721 & 787 \\
\hline General sales tax & 596 & 827 & 1,024 & 1,219 & 1,354 & 1,354 & 1,354 & 1,509 & 1,659 & 1,808 & 1,965 & 2,135 \\
\hline Taxes on foreign trade & 209 & 267 & 305 & 316 & 338 & 338 & 338 & 374 & 407 & 439 & 472 & 507 \\
\hline Nontax revenue, of which: & 582 & 650 & 756 & 987 & 988 & 988 & 990 & 1,147 & 1,266 & 1,370 & 1,459 & 1,580 \\
\hline Fees & 249 & 324 & 424 & 503 & 520 & 520 & 520 & 561 & 604 & 649 & 698 & 750 \\
\hline Oil surplus & 23 & 0 & 0 & 0 & 10 & 10 & 0 & 88 & 135 & 160 & 159 & 183 \\
\hline Grants & 846 & 883 & 449 & 333 & 574 & 574 & 574 & 250 & 250 & 250 & 250 & 250 \\
\hline Total expenditures & 2,585 & 3,102 & 3,421 & 3,834 & 4,231 & 4,309 & 4,254 & 4,344 & 4,656 & 5,017 & 5,399 & 5,822 \\
\hline Current expenditure & 2,057 & 2,327 & 2,935 & 3,186 & 3,320 & 3,398 & 3,357 & 3,435 & 3,654 & 3,931 & 4,251 & 4,592 \\
\hline Wages and salaries & 419 & 443 & 493 & 518 & 552 & 582 & 582 & 651 & 712 & 777 & 848 & 926 \\
\hline Interest payments & 270 & 229 & 266 & 318 & 393 & 393 & 389 & 449 & 511 & 531 & 546 & 551 \\
\hline Domestic & 61 & 64 & 94 & 133 & 188 & 188 & 184 & 239 & 303 & 325 & 349 & 361 \\
\hline External & 209 & 166 & 172 & 185 & 205 & 205 & 205 & 210 & 208 & 206 & 198 & 190 \\
\hline Military expenditure & 629 & 653 & 699 & 792 & 1,133 & 1,163 & 1,163 & 1,052 & 1,088 & 1,187 & 1,295 & 1,415 \\
\hline Fuel subsidies & 0 & 260 & 501 & 279 & 0 & 0 & 0 & 0 & 0 & 0 & 0 & 0 \\
\hline Food subsidies & 0 & 0 & 55 & 85 & 60 & 60 & 60 & 42 & 24 & 0 & 0 & 0 \\
\hline Transfers & 582 & 572 & 674 & 926 & 862 & 880 & 850 & 915 & 982 & 1,066 & 1,159 & 1,260 \\
\hline Of which: pensions & 346 & 377 & 434 & 491 & 525 & 543 & 543 & 605 & 662 & 722 & 788 & 861 \\
\hline Purchases of goods \& services and other & 94 & 170 & 247 & 268 & 321 & 321 & 314 & 327 & 338 & 369 & 403 & 440 \\
\hline Capital expenditure $2 /$ & 601 & 725 & 532 & 696 & 841 & 841 & 826 & 897 & 988 & 1,072 & 1,132 & 1,212 \\
\hline \multirow[t]{2}{*}{ Net lending and nonbudget spending } & -72 & 50 & -46 & -47 & 70 & 70 & 70 & 12 & 13 & 15 & 16 & 17 \\
\hline & \multicolumn{12}{|c|}{ (In percent of annual GDP) } \\
\hline Total revenue and grants & 34.7 & 36.7 & 33.0 & 34.2 & 34.6 & 34.6 & 34.8 & 32.4 & 32.4 & 32.1 & 31.7 & 31.4 \\
\hline Domestic revenue & 23.0 & 25.7 & 28.0 & 30.9 & 29.6 & 29.6 & 29.8 & 30.4 & 30.6 & 30.5 & 30.1 & 29.9 \\
\hline Tax revenue, of which: & 15.0 & 17.7 & 19.6 & 21.1 & 20.8 & 20.8 & 21.0 & 21.2 & 21.3 & 21.3 & 21.2 & 21.0 \\
\hline Taxes on income and profits & 2.7 & 2.7 & 3.1 & 4.1 & 4.2 & 4.2 & 4.3 & 4.4 & 4.4 & 4.4 & 4.4 & 4.4 \\
\hline General sales tax & 8.3 & 10.2 & 11.4 & 12.1 & 12.0 & 12.0 & 12.0 & 12.1 & 12.2 & 12.1 & 12.1 & 12.0 \\
\hline Taxes on foreign trade & 2.9 & 3.3 & 3.4 & 3.1 & 3.0 & 3.0 & 3.0 & 3.0 & 3.0 & 2.9 & 2.9 & 2.9 \\
\hline Nontax revenue, of which: & 8.1 & 8.0 & 8.4 & 9.8 & 8.7 & 8.7 & 8.7 & 9.2 & 9.3 & 9.2 & 9.0 & 8.9 \\
\hline Fees & 3.4 & 4.0 & 4.7 & 5.0 & 4.6 & 4.6 & 4.6 & 4.5 & 4.4 & 4.4 & 4.3 & 4.2 \\
\hline Oil surplus & 0.3 & 0.0 & 0.0 & 0.0 & 0.1 & 0.1 & 0.0 & 0.7 & 1.0 & 1.1 & 1.0 & 1.0 \\
\hline Grants & 11.7 & 10.9 & 5.0 & 3.3 & 5.1 & 5.1 & 5.1 & 2.0 & 1.8 & 1.7 & 1.5 & 1.4 \\
\hline Total expen & 35.8 & 38.4 & 38.0 & 37.9 & 37.4 & 38.1 & 37.6 & 34.8 & 34.1 & 33.7 & 33.2 & 32.8 \\
\hline Current expenditure & 28.5 & 28.8 & 32.6 & 31.5 & 29.3 & 30.0 & 29.6 & 27.5 & 26.8 & 26.4 & 26.2 & 25.9 \\
\hline Wages and salaries & 5.8 & 5.5 & 5.5 & 5.1 & 4.9 & 5.1 & 5.1 & 5.2 & 5.2 & 5.2 & 5.2 & 5.2 \\
\hline Interest payments & 3.7 & 2.8 & 3.0 & 3.1 & 3.5 & 3.5 & 3.4 & 3.6 & 3.7 & 3.6 & 3.4 & 3.1 \\
\hline Domestic & 0.8 & 0.8 & 1.0 & 1.3 & 1.7 & 1.7 & 1.6 & 1.9 & 2.2 & 2.2 & 2.1 & 2.0 \\
\hline External & 2.9 & 2.0 & 1.9 & 1.8 & 1.8 & 1.8 & 1.8 & 1.7 & 1.5 & 1.4 & 1.2 & 1.1 \\
\hline Military expenditure & 8.7 & 8.1 & 7.8 & 7.8 & 10.0 & 10.3 & 10.3 & 8.4 & 8.0 & 8.0 & 8.0 & 8.0 \\
\hline Fuel subsidy & 0.0 & 3.2 & 5.6 & 2.8 & 0.0 & 0.0 & 0.0 & 0.0 & 0.0 & 0.0 & 0.0 & 0.0 \\
\hline Food subsidy & 0.0 & 0.0 & 0.6 & 0.8 & 0.5 & 0.5 & 0.5 & 0.3 & 0.2 & 0.0 & 0.0 & 0.0 \\
\hline Transfers & 8.0 & 7.1 & 7.5 & 9.2 & 7.6 & 7.8 & 7.5 & 7.3 & 7.2 & 7.2 & 7.1 & 7.1 \\
\hline Of which: pensions & 4.8 & 4.7 & 4.8 & 4.9 & 4.6 & 4.8 & 4.8 & 4.8 & 4.8 & 4.8 & 4.8 & 4.8 \\
\hline Purchases of goods \& services and other & 1.3 & 2.1 & 2.7 & 2.7 & 2.8 & 2.8 & 2.8 & 2.6 & 2.5 & 2.5 & 2.5 & 2.5 \\
\hline Capital expenditure 2/ & 8.3 & 9.0 & 5.9 & 6.9 & 7.4 & 7.4 & 7.3 & 7.2 & 7.2 & 7.2 & 7.0 & 6.8 \\
\hline Net lending and nonbudget spending & -1.0 & 0.6 & -0.5 & -0.5 & 0.6 & 0.6 & 0.6 & 0.1 & 0.1 & 0.1 & 0.1 & 0.1 \\
\hline
\end{tabular}

Sources: Jordanian authorities; and Fund staff projections.

1 / Staff projections are in line with the policy framework agreed with the authorities.

$2 /$ Includes some current expenditure, such as maintenance and wage-related spending. 
Table 7. Jordan: Summary Monetary Survey, 2003-08

\begin{tabular}{|c|c|c|c|c|c|c|}
\hline & $\begin{array}{l}\text { Dec. } \\
2003\end{array}$ & $\begin{array}{l}\text { Dec. } \\
2004\end{array}$ & $\begin{array}{l}\text { Dec. } \\
2005\end{array}$ & $\begin{array}{l}\frac{\text { Prel. }}{\text { Dec. }} \\
2006\end{array}$ & $\begin{array}{l}\frac{\text { Proj. }}{\text { Dec. }} \\
2007\end{array}$ & $\begin{array}{l}\text { Proj. } \\
\text { Dec. } \\
2008\end{array}$ \\
\hline & \multicolumn{6}{|c|}{ (Stocks in millions of Jordanian dinars) } \\
\hline Net foreign assets & 5,489 & 5,884 & 6,058 & 7,416 & 7,812 & 7,773 \\
\hline Net domestic assets & 3,977 & 4,688 & 6,306 & 6,694 & 7,996 & 9,636 \\
\hline Net claims on central government $1 /$ & 1,352 & 1,326 & 1,744 & 1,454 & 1,661 & 2,143 \\
\hline Of which: budgetary central government $2 /$ & 1,396 & 1,518 & 1,853 & 1,819 & 1,854 & 2,336 \\
\hline Claims on nonfinancial public enterprises & 278 & 473 & 528 & 521 & 583 & 642 \\
\hline Claims on financial institutions & 73 & 95 & 153 & 214 & 218 & 218 \\
\hline Claims on the private sector & 5,016 & 5,885 & 7,669 & 9,546 & 11,034 & 12,690 \\
\hline Other items (net) & $-2,741$ & $-3,101$ & $-3,787$ & $-5,041$ & $-5,500$ & $-6,057$ \\
\hline Broad money & 9,466 & 10,571 & 12,364 & 14,110 & 15,807 & 17,409 \\
\hline Currency in circulation & 1,444 & 1,414 & 1,657 & 2,027 & 2,109 & 2,272 \\
\hline Jordanian dinar deposits & 5,800 & 6,455 & 7,795 & 8,760 & 10,140 & 11,250 \\
\hline \multirow[t]{2}{*}{ Foreign currency deposits } & 2,222 & 2,702 & 2,912 & 3,322 & 3,559 & 3,887 \\
\hline & \multicolumn{6}{|c|}{ (Cumulative flows in millions of Jordanian dinars) } \\
\hline Net foreign assets & 1,081 & 395 & 174 & 1,358 & 396 & -39 \\
\hline Net domestic assets & -34 & 710 & 1,619 & 388 & 1,302 & 1,640 \\
\hline Net claims on central government $1 /$ & -5 & -25 & 418 & -291 & 207 & 482 \\
\hline Of which: budgetary central government 2/ & -10 & 122 & 335 & -33 & 34 & 482 \\
\hline Claims on nonfinancial public enterprises & 17 & 195 & 56 & -8 & 63 & 59 \\
\hline Claims on financial institutions & -1 & 21 & 58 & 62 & 3 & 0 \\
\hline Claims on the private sector & 168 & 870 & 1,784 & 1,878 & 1,488 & 1,656 \\
\hline Other items (net) & -213 & -360 & -686 & $-1,254$ & -459 & -557 \\
\hline Broad money & 1,047 & 1,106 & 1,793 & 1,746 & 1,698 & 1,601 \\
\hline Currency in circulation & 191 & -29 & 243 & 370 & 81 & 163 \\
\hline Jordanian dinar deposits & 582 & 656 & 1,340 & 965 & 1,380 & 1,110 \\
\hline \multirow[t]{2}{*}{ Foreign currency deposits } & 274 & 480 & 210 & 411 & 237 & 328 \\
\hline & \multicolumn{6}{|c|}{ (Cumulative flows in percent of beginning-of-period broad money) } \\
\hline Net foreign assets & 12.8 & 4.2 & 1.6 & 11.0 & 2.8 & -0.2 \\
\hline Net domestic assets & -0.4 & 7.5 & 15.3 & 3.1 & 9.2 & 10.4 \\
\hline Net claims on general government $1 /$ & -0.1 & -0.3 & 4.0 & -2.4 & 1.5 & 3.0 \\
\hline Of which: budgetary central government 2/ & -0.1 & 1.3 & 3.2 & -0.3 & 0.2 & 3.0 \\
\hline Claims on nonfinancial public enterprises & 0.2 & 2.1 & 0.5 & -0.1 & 0.4 & 0.4 \\
\hline Claims on financial institutions & 0.0 & 0.2 & 0.5 & 0.5 & 0.0 & 0.0 \\
\hline Claims on the private sector & 2.0 & 9.2 & 16.9 & 15.2 & 10.5 & 10.5 \\
\hline Other items (net) & -2.5 & -3.8 & -6.5 & -10.1 & -3.3 & -3.5 \\
\hline Broad money & 12.4 & 11.7 & 17.0 & 14.1 & 12.0 & 10.1 \\
\hline Currency in circulation & 2.3 & -0.3 & 2.3 & 3.0 & 0.6 & 1.0 \\
\hline Jordanian dinar deposits & 6.9 & 6.9 & 12.7 & 7.8 & 9.8 & 7.0 \\
\hline Foreign currency deposits & 3.3 & 5.1 & 2.0 & 3.3 & 1.7 & 2.1 \\
\hline \multicolumn{7}{|l|}{ Memorandum items: } \\
\hline Annual broad money growth (percent) & 12.4 & 11.7 & 17.0 & 14.1 & 12.0 & 10.1 \\
\hline Annual JD broad money growth (percent) & 11.9 & 8.6 & 20.1 & 14.1 & 13.5 & 10.4 \\
\hline Annual net domestic assets growth (percent) & -0.8 & 17.9 & 34.5 & 6.1 & 19.4 & 20.5 \\
\hline Annual private sector credit growth (percent) & 3.5 & 17.3 & 30.3 & 24.5 & 15.6 & 15.0 \\
\hline Foreign currency/total deposits (percent) & 27.7 & 29.5 & 27.2 & 27.5 & 26.0 & 25.7 \\
\hline Private sector credit/total deposits (percent) & 62.5 & 64.3 & 71.6 & 79.0 & 80.6 & 83.8 \\
\hline Currency/JD deposits (percent) & 24.9 & 21.9 & 21.3 & 23.1 & 20.8 & 20.2 \\
\hline
\end{tabular}

Sources: Central Bank of Jordan; and Fund staff estimates and projections.

$1 /$ Includes central budgetary government and own-budget agencies, but excludes SSC.

2/ Excludes UN compensation funds and Brady bonds held by Jordanian banks. 
Table 8. Jordan: Summary Accounts of the Central Bank of Jordan, 2003-08

\begin{tabular}{|c|c|c|c|c|c|c|}
\hline & $\begin{array}{l}\text { Dec. } \\
2003\end{array}$ & $\begin{array}{l}\text { Dec. } \\
2004\end{array}$ & $\begin{array}{l}\text { Dec. } \\
2005\end{array}$ & $\begin{array}{l}\frac{\text { Prel. }}{\text { Dec. }} \\
2006\end{array}$ & $\begin{array}{l}\text { Proj. } \\
\text { Dec. } \\
2007\end{array}$ & $\begin{array}{l}\text { Proj. } \\
\text { Dec. } \\
2008\end{array}$ \\
\hline & \multicolumn{6}{|c|}{ (Stocks in millions of Jordanian dinars) } \\
\hline Net foreign assets & 3,906 & 4,039 & 4,059 & 4,990 & 5,317 & 5,287 \\
\hline Net domestic assets & $-1,619$ & $-1,677$ & $-1,239$ & $-1,605$ & $-1,767$ & $-1,478$ \\
\hline Net claims on central government $1 /$ & 732 & 580 & 859 & 147 & 7 & 33 \\
\hline Net claims on NFPEs and the SSC & -128 & -87 & -24 & -19 & -23 & -23 \\
\hline Net claims on financial institutions & 24 & 26 & 75 & 94 & 85 & 85 \\
\hline Net claims on private sector & 15 & 18 & 18 & 18 & 18 & 18 \\
\hline Net claims on commercial banks & 87 & 312 & 151 & 440 & 252 & 252 \\
\hline CDs & $-2,176$ & $-2,534$ & $-2,280$ & $-2,153$ & $-2,010$ & $-1,747$ \\
\hline Other items, net (asset: + ) & -172 & 8 & -39 & -131 & -96 & -96 \\
\hline Jordanian dinar reserve money & 2,287 & 2,362 & 2,821 & 3,386 & 3,550 & 3,809 \\
\hline Currency & 1,535 & 1,508 & 1,783 & 2,201 & 2,246 & 2,409 \\
\hline Commercial bank reserves & 751 & 855 & 1,038 & 1,185 & 1,304 & 1,400 \\
\hline \multirow[t]{2}{*}{ Of which: required reserves } & 428 & 452 & 566 & 715 & 833 & 925 \\
\hline & \multicolumn{6}{|c|}{ (Cumulative flows in millions of Jordanian dinars from beginning of period) } \\
\hline Net foreign assets & 969 & 134 & 20 & 931 & 327 & -31 \\
\hline Net domestic assets & -576 & -58 & 438 & -366 & -163 & 290 \\
\hline Net claims on central government $1 /$ & 149 & -152 & 278 & -712 & -139 & 26 \\
\hline Net claims on NFPEs and the SSC & -73 & 42 & 63 & 4 & -4 & 0 \\
\hline Net claims on financial institutions & 0 & 1 & 50 & 18 & -9 & 0 \\
\hline Net claims on private sector & 1 & 3 & 0 & -1 & 0 & 0 \\
\hline Net claims on commercial banks & -34 & 225 & -161 & 289 & -187 & 0 \\
\hline CDs & -533 & -358 & 255 & 127 & 143 & 264 \\
\hline Other items, net (asset: + ) & -86 & 180 & -47 & -92 & 34 & 0 \\
\hline Jordanian dinar reserve money & 393 & 76 & 458 & 565 & 165 & 259 \\
\hline Currency & 202 & -28 & 276 & 418 & 45 & 163 \\
\hline \multirow[t]{2}{*}{ Commercial banks' reserves } & 190 & 104 & 183 & 147 & 120 & 95 \\
\hline & \multicolumn{6}{|c|}{ (Cumulative flows in percent of beginning-of-period reserve money) } \\
\hline Net foreign assets & 51.2 & 5.8 & 0.9 & 33.0 & 9.7 & -0.9 \\
\hline Net domestic assets & -30.4 & -2.5 & 18.5 & -13.0 & -4.8 & 8.2 \\
\hline Net claims on central government $1 /$ & 7.9 & -6.6 & 11.8 & -25.2 & -4.1 & 0.7 \\
\hline Net claims on NFPEs and the SSC & -3.8 & 1.8 & 2.7 & 0.2 & -0.1 & 0.0 \\
\hline Net claims on financial institutions & 0.0 & 0.1 & 2.1 & 0.7 & -0.3 & 0.0 \\
\hline Net claims on private sector & 0.0 & 0.1 & 0.0 & 0.0 & 0.0 & 0.0 \\
\hline Net claims on commercial banks & -1.8 & 9.8 & -6.8 & 10.2 & -5.5 & 0.0 \\
\hline CDs & -28.1 & -15.7 & 10.8 & 4.5 & 4.2 & 7.4 \\
\hline Other items, net (asset: + ) & -4.5 & 7.9 & -2.0 & -3.3 & 1.0 & 0.0 \\
\hline Jordanian dinar reserve money & 20.7 & 3.3 & 19.4 & 20.0 & 4.9 & 7.3 \\
\hline Currency & 10.7 & -1.2 & 11.7 & 14.8 & 1.3 & 4.6 \\
\hline Commercial bank reserves & 10.0 & 4.5 & 7.7 & 5.2 & 3.5 & 2.7 \\
\hline \multicolumn{7}{|l|}{ Memorandum items: } \\
\hline Gross usable international reserves (\$ millions) & 4,740 & 4,826 & 4,745 & 6,104 & 6,450 & 6,350 \\
\hline As a ratio to JD broad money (in percent) & 46.4 & 43.5 & 35.6 & 40.1 & 37.3 & 33.3 \\
\hline As a ratio of JD reserve money (in percent) & 147.0 & 144.8 & 119.3 & 127.8 & 128.8 & 118.2 \\
\hline Net international reserves (JD millions) $2 /$ & 3,142 & 3,222 & 3,277 & 4,276 & 4,551 & 4,520 \\
\hline Money multiplier (for JD liquidity) & 3.17 & 3.33 & 3.35 & 3.19 & 3.45 & 3.55 \\
\hline
\end{tabular}

Sources: CBJ; and Fund staff estimates and projections.

1/ Excludes UN compensation funds and Brady bonds held by Jordanian banks.

2/ Excludes foreign assets pledged as collateral for the 1993 commercial debt restructuring and the yearly change in foreign currency swaps. 
Table 9. Jordan: Central Government Medium-Term External Debt and Debt Service, 2003-12

\begin{tabular}{|c|c|c|c|c|c|c|c|c|c|c|}
\hline & \multirow[b]{2}{*}{2003} & \multirow[b]{2}{*}{2004} & \multirow{2}{*}{$\frac{\text { Prel. }}{2005}$} & \multirow{2}{*}{$\frac{\text { Est. }}{2006}$} & \multicolumn{6}{|c|}{ Projections } \\
\hline & & & & & 2007 & 2008 & 2009 & 2010 & 2011 & 2012 \\
\hline & & & & (In millic & ns of Jo & danian o & nars) & & & \\
\hline \multirow[t]{2}{*}{ Total government external debt $1 /$} & 5,388 & 5,347 & 5,057 & 5,186 & 5,103 & 4,900 & 4,693 & 4,469 & 4,215 & 3,937 \\
\hline & \multicolumn{10}{|c|}{ (In millions of U.S. dollars) } \\
\hline Total government external debt $1 /$ & 7,599 & 7,541 & 7,132 & 7,315 & 7,198 & 6,911 & 6,619 & 6,303 & 5,946 & 5,553 \\
\hline Medium- and long-term debt (excl IMF) & 7,183 & 7,206 & 6,896 & 7,157 & 7,115 & 6,884 & 6,615 & 6,303 & 5,946 & 5,553 \\
\hline To bilateral and multilateral creditors $1 /$ & 7,092 & 7,183 & 6,886 & 7,151 & 7,109 & 6,879 & 6,610 & 6,297 & 5,940 & 5,547 \\
\hline To London Club creditors & 25 & 13 & 3 & 2 & 2 & 2 & 2 & 2 & 2 & 2 \\
\hline Of which: collateralized Brady bonds & 0 & 0 & 0 & 0 & 0 & 0 & 0 & 0 & 0 & 0 \\
\hline To other creditors & 66 & 10 & 7 & 4 & 4 & 4 & 4 & 4 & 4 & 4 \\
\hline Use of Fund resources & 416 & 335 & 237 & 159 & 83 & 27 & 4 & 0 & 0 & 0 \\
\hline Service on government external debt $1 / 2 / 3 /$ & 860 & 902 & 819 & 840 & 890 & 827 & 850 & 881 & 921 & 946 \\
\hline Of which: to the Fund & 112 & 108 & 88 & 105 & 83 & 61 & 25 & 5 & 1 & 0 \\
\hline Amortization 1/2/ & 541 & 649 & 550 & 552 & 573 & 511 & 536 & 571 & 621 & 657 \\
\hline Of which: to the Fund & 100 & 98 & 77 & 96 & 74 & 56 & 23 & 4 & 0 & 0 \\
\hline Interest & 318 & 253 & 269 & 288 & 317 & 316 & 314 & 311 & 299 & 289 \\
\hline \multirow[t]{2}{*}{ Of which: to the Fund } & 12 & 10 & 10 & 9 & 8 & 5 & 2 & 1 & 1 & 0 \\
\hline & \multicolumn{10}{|c|}{ (In percent of GDP) } \\
\hline Total government external debt 1 / & 74.5 & 66.2 & 56.1 & 51.3 & 45.1 & 39.3 & 34.4 & 30.0 & 25.9 & 22.2 \\
\hline Medium- and long-term debt & 70.5 & 63.2 & 54.2 & 50.2 & 44.5 & 39.1 & 34.4 & 30.0 & 25.9 & 22.2 \\
\hline Use of Fund resources & 4.1 & 2.9 & 1.9 & 1.1 & 0.5 & 0.2 & 0.0 & 0.0 & 0.0 & 0.0 \\
\hline Service on government external debt $1 /$ & 8.4 & 7.9 & 6.4 & 5.9 & 5.6 & 4.7 & 4.4 & 4.2 & 4.0 & 3.8 \\
\hline Amortization & 5.3 & 5.7 & 4.3 & 3.9 & 3.6 & 2.9 & 2.8 & 2.7 & 2.7 & 2.6 \\
\hline \multirow[t]{2}{*}{ Interest } & 3.1 & 2.2 & 2.1 & 2.0 & 2.0 & 1.8 & 1.6 & 1.5 & 1.3 & 1.2 \\
\hline & \multicolumn{10}{|c|}{ (In percent of exports of goods and nonfactor services) } \\
\hline Total government external debt $1 /$ & 157.6 & 126.6 & 107.5 & 95.2 & 81.5 & 70.0 & 60.3 & 51.8 & 44.3 & 37.5 \\
\hline Of which: to the Fund & 8.6 & 5.6 & 3.6 & 2.1 & 0.9 & 0.3 & 0.0 & 0.0 & 0.0 & 0.0 \\
\hline Service on government external debt $1 /$ & 17.8 & 15.1 & 12.3 & 10.9 & 10.1 & 8.4 & 7.7 & 7.2 & 6.9 & 6.4 \\
\hline Of which: to the Fund & 2.3 & 1.8 & 1.3 & 1.4 & 0.9 & 0.6 & 0.2 & 0.0 & 0.0 & 0.0 \\
\hline Amortization 2/ 3/ & 11.2 & 10.9 & 8.3 & 7.2 & 6.5 & 5.2 & 4.9 & 4.7 & 4.6 & 4.4 \\
\hline Of which: to the Fund & 2.1 & 1.6 & 1.2 & 1.2 & 0.8 & 0.6 & 0.2 & 0.0 & 0.0 & 0.0 \\
\hline Interest & 6.6 & 4.2 & 4.1 & 3.7 & 3.6 & 3.2 & 2.9 & 2.6 & 2.2 & 2.0 \\
\hline Of which: to the Fund & 0.3 & 0.2 & 0.2 & 0.1 & 0.1 & 0.0 & 0.0 & 0.0 & 0.0 & 0.0 \\
\hline
\end{tabular}

Sources: Jordanian authorities; and Fund staff estimates and projections.

1/ Includes government-guaranteed external debt.

2/ On a commitment basis.

3/ For 2003 , includes prepayments of $\$ 456$ million. 


\section{APPENDIX I: EXTERNAL DEBT SUSTAINABILITY ANALYSIS}

The external debt sustainability outlook is broadly unchanged from staff's assessment at the time of the 2006 Article IV report. In particular, external debt is still expected to be halved in five years under the staff's baseline scenario (Table A.1). Besides favorable macroeconomic policies, most notably fiscal adjustment, this assumes a continuation of the cautious external borrowing policies of recent years, which have reduced annual external borrowing to an average of nearly 2 percent of GDP in 2005-06, half the borrowing rate in the early part of the decade. The projections also reflect expectations that Jordan will rely predominantly on concessional sources of external financing over the next five years (mainly the World Bank and regional development banks), though some portion of external financing is expected to be sourced from sovereign bond issues. Finally, the DSA reflects staff's views that, despite declining official grants over the medium term, the external outlook is benign, given the support to exports provided by the U.S. free trade agreement and strong regional demand, WEO forecasts of falling import unit values, and favorable regional liquidity conditions (reflected in continued strong investor commitments) that should continue to provide nondebt-creating financing in the form of FDI (mainly from Kuwait, Saudi Arabia, and UAE).

The debt reduction path is robust to the usual bound tests, but remains quite sensitive to an assumed sharp decline in nondebt-creating capital inflows:

- Standard bound tests (Figure A.1) reveal that the debt-to-GDP ratio is generally robust to shocks in the external interest rate or GDP growth. A sharp depreciation would lead to an immediate deterioration in the debt ratio, but would not have an adverse impact over time, provided other assumptions remain achievable. If key variables are held at their historical averages, Jordan's debt would fall even faster than expected (and imply a rising net creditor position to the rest of the world), due to the high current account surpluses that characterized most of the pre-2003 period.

- Given the still large current account deficit, the main source of risk is a decline in (nondebt-creating) capital inflows that is much sharper than already expected. To assess the impact of such a decline, a shock scenario is considered in which capital inflows remain strong this year, but fall sharply to the historical average for the remainder of the projection period. This scenario shows that the debt ratio would show almost no improvement from current levels, leaving the economy more exposed to other shocks.

Overall, the DSA shows that policies that help reduce the current account deficit and maintain the recent growth and FDI momentum would continue to provide the basis for a sustainable debt position. 

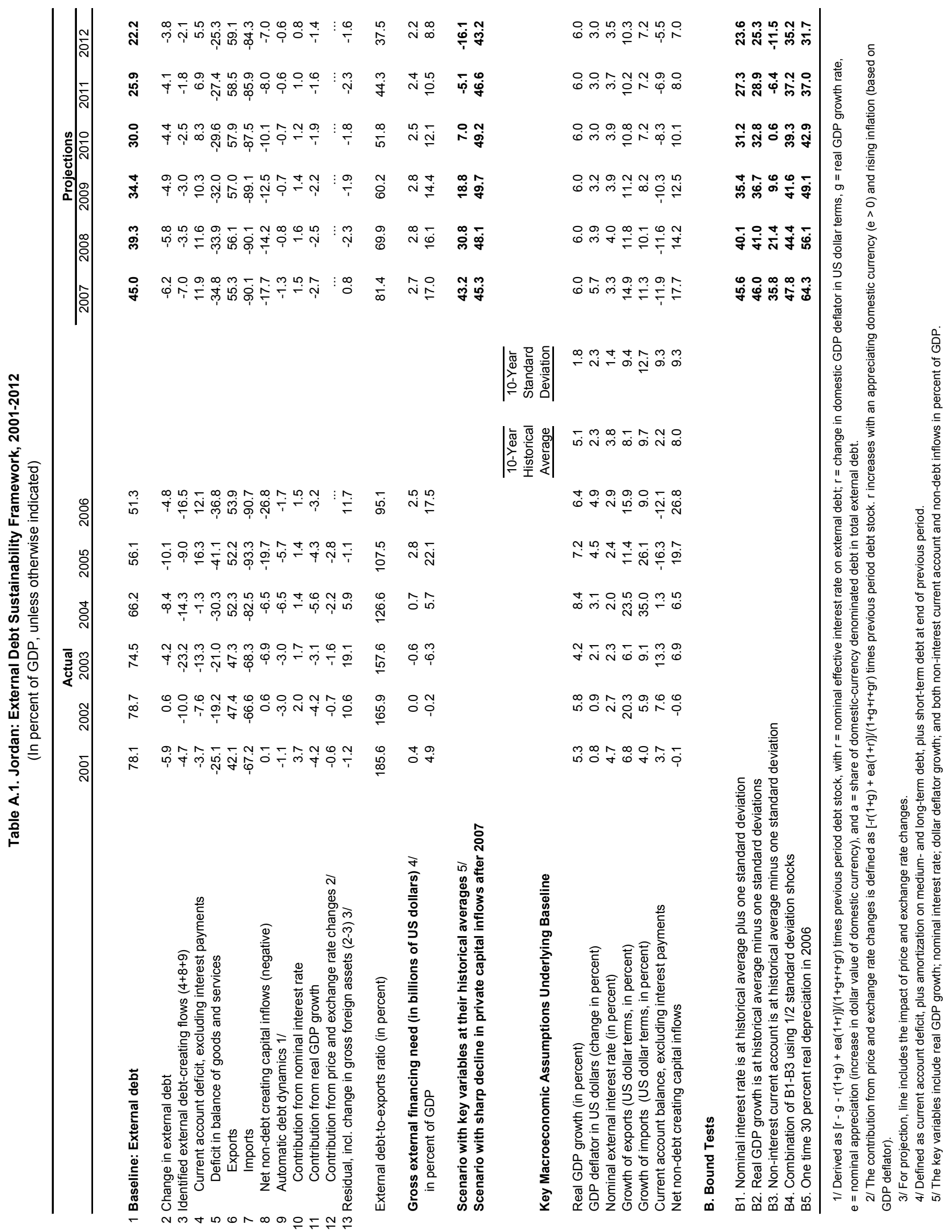
Figure A.1. Jordan: External Debt Sustainability: Bound Tests 1/ (External debt in percent of GDP)
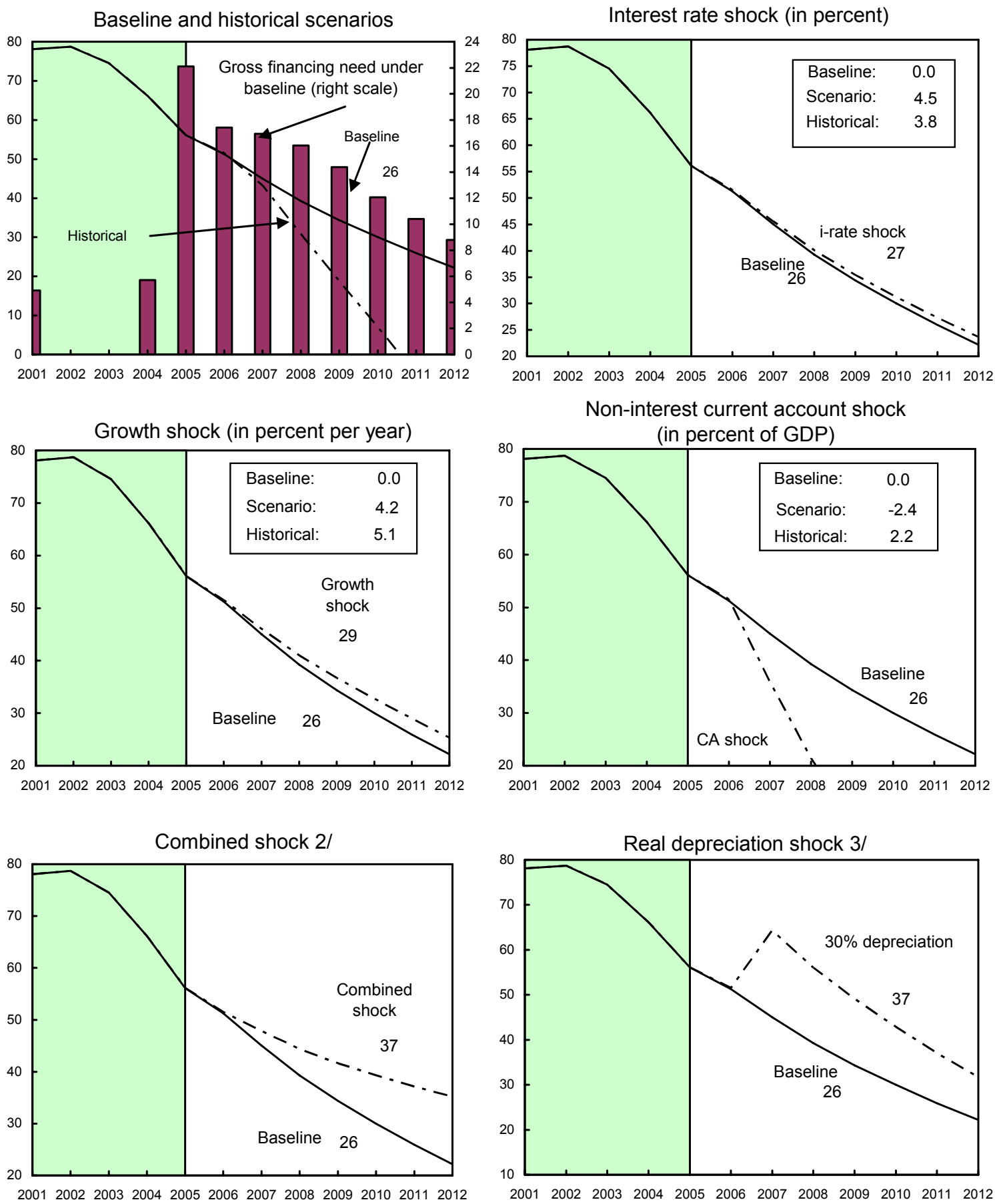

Sources: Jordanian authorities; and Fund staff estimates.

$1 /$ Shaded areas represent actual data. Individual shocks are permanent one-half standard deviation shocks. Figures in the boxes represent average projections for the respective variables in the baseline and scenario being presented. Ten-year historical average for the variable is also shown.

2/ Permanent 1/4 standard deviation shocks applied to real interest rate, growth rate, and current account balance.

3/ One-time real depreciation of 30 percent occurs in 2006. 


\section{ApPendix II: Public DebT Sustainability Analysis}

Public and publicly guaranteed debt is expected to decline steadily to about 52 percent of GDP by end-2011 under the baseline scenario (Table A.2). Fiscal adjustment is expected to proceed as discussed in the main text, anchored by the new medium-term debt goal. Also, the government is assumed to continue to abstain from short-term and commercial borrowing, and external borrowing is expected to decline as the domestic financial market continues to strengthen. The following discusses briefly the impact of most relevant external shocks to both public and external debt sustainability.

\section{Although baseline projections show a large decline in the debt burden, this outcome is} vulnerable to large shocks. Standard bound tests (Figure A.2) reveal that:

- Under a 30 percent real effective depreciation, the public debt ratio would first jump sharply before returning to current levels by end-2011.

- If real GDP growth during 2007-11 were to be a half standard deviation below the baseline, the public debt burden would still decline sharply, but would be 6 percentage points of GDP higher than under the baseline by end-2011. Half standard deviation permanent shocks to real interest rates or to the primary balance have a somewhat smaller medium-term impact. By contrast, the impact of a contingent liabilities shock-which is assumed to increase the debt ratio by 10 percent of GDP in 2007—would be a little higher.

- With combined, small but permanent shocks ( $1 / 4$ historical standard deviation) on real interest rates, real growth, and the fiscal primary balance in 2007-12, the debt-to-GDP ratio would decline sharply but exceed the baseline by 5 percentage points by end-2011.

Jordan's debt profile is heavily dependent on adjustment policies, which are key to meeting the new 60 percent of GDP debt target by end-2011. A no-policy-change scenario assumes that the primary deficit of 2006 ( 0.6 percent of GDP) is kept constant during 2007-11. While the public debt ratio would decline initially, the trend would reverse toward the end of the projection period, and, at about 66 percent of GDP at end-2011, the debt ratio would be well above the new debt target. 


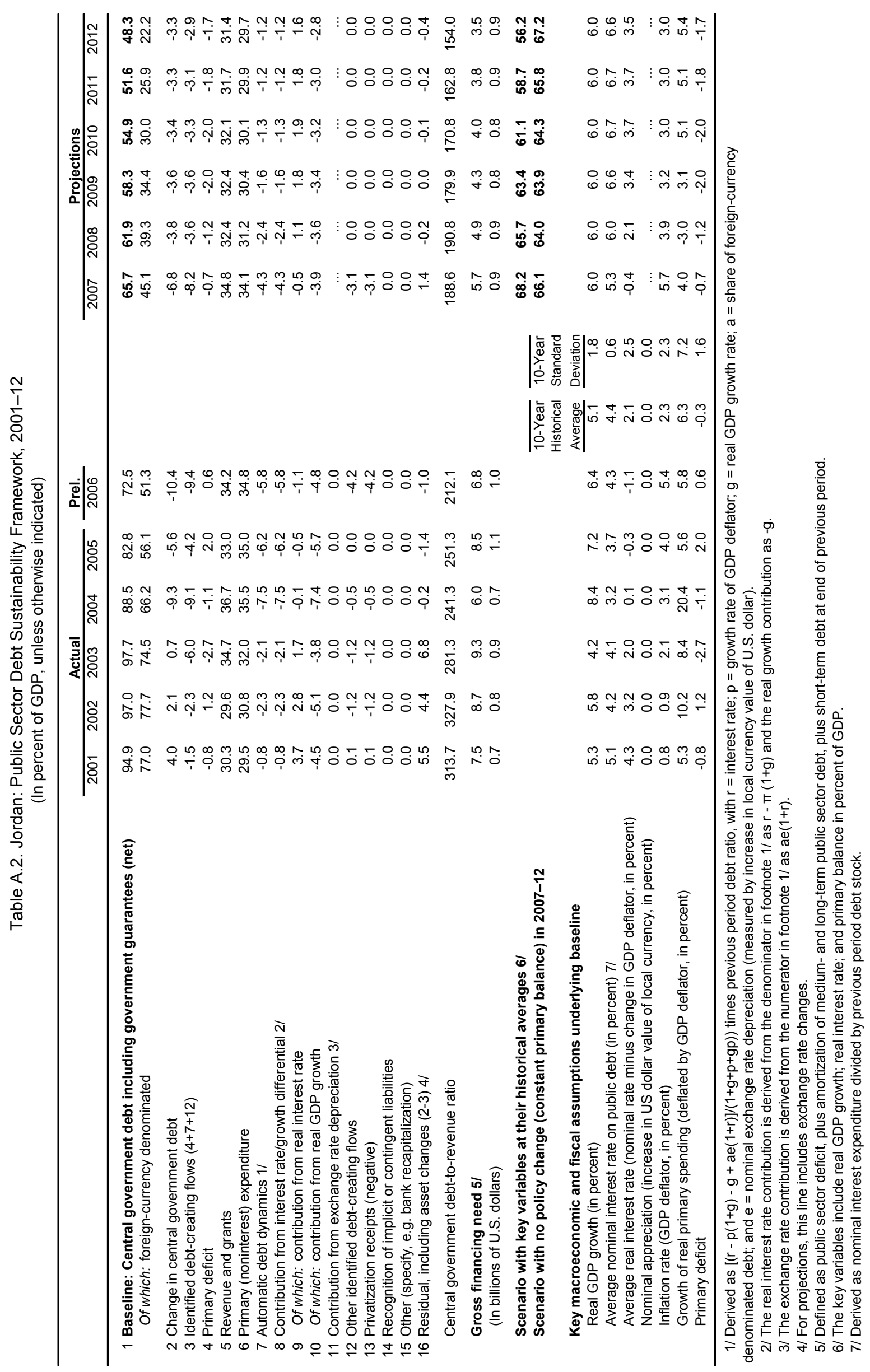


Figure A.2. Jordan: Public Debt Sustainability: Bound Tests 1/ (Public debt in percent of GDP)
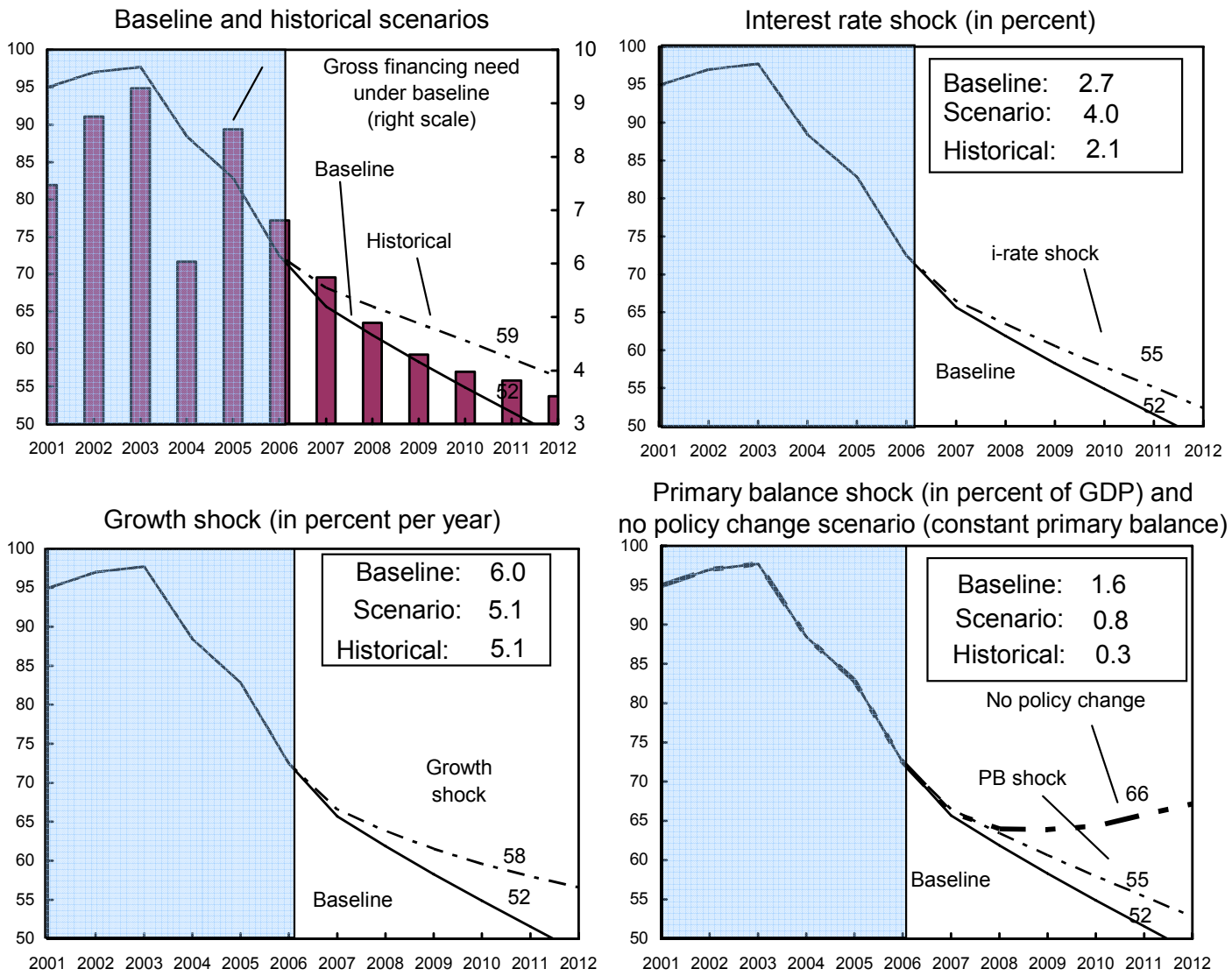

Primary balance shock (in percent of GDP) and no policy change scenario (constant primary balance)

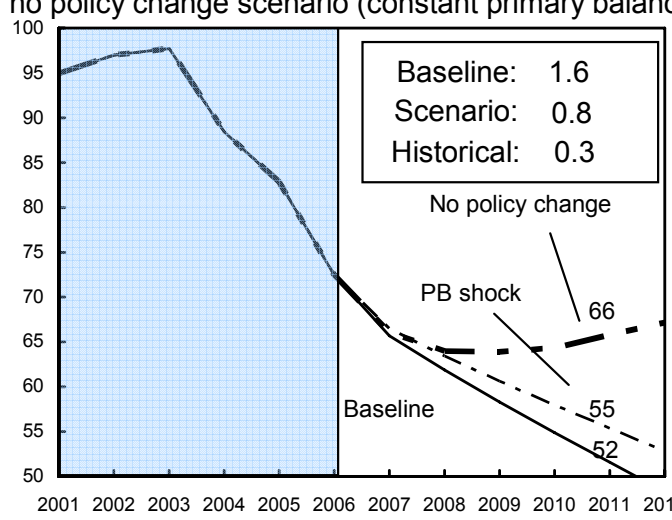

Combined shock 2/
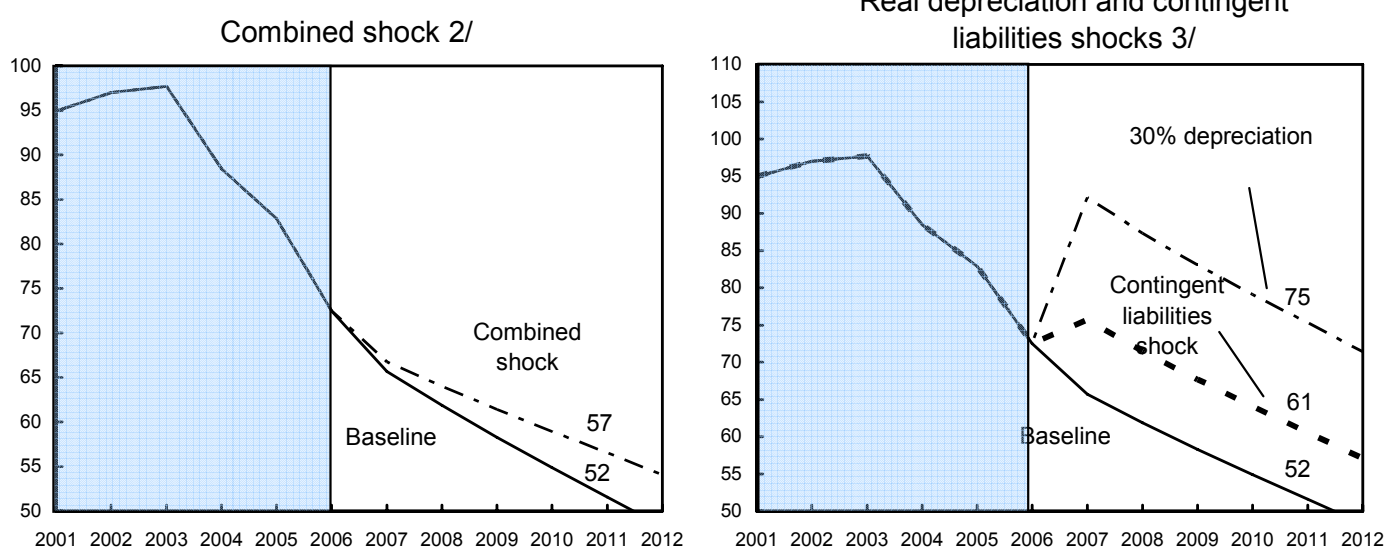

Sources: Jordanian authorities; and Fund staff estimates.

1/ Shaded areas represent actual data. Individual shocks are permanent $1 / 2$ standard deviation shocks. Figures in the boxes represent average projections for the respective variables in the baseline and scenario being presented. The end-period values are also shown.

2/ Permanent $1 / 4$ standard deviation shocks applied to real interest rate, growth rate, and primary balance.

3/ One-time real depreciation of 30 percent and 10 percent of GDP shock to contingent liabilities occur in 2007, with real depreciation defined as nominal depreciation (measured by percentage fall in dollar value of local currency) minus domestic inflation (based on GDP deflator). 


\section{INTERNATIONAL MONETARY FUND JORDAN \\ Fifth Post-Program Monitoring Discussions Informational Annex}

\section{Prepared by the Middle East and Central Asia Department \\ (In consultation with other departments)}

June 8, 2007

Contents

Appendixes

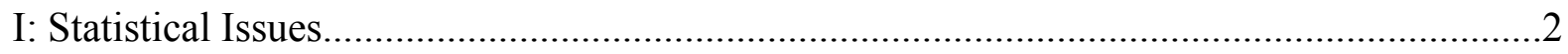

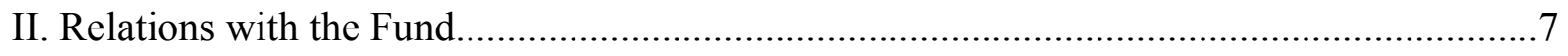

III. World Bank Group Strategy and Operations ........................................................... 10 


\section{APPENDIX I: STATISTICAL ISSUES}

1. The quality and timeliness of data are adequate to conduct Article IV consultation and post-program monitoring discussions.

2. A mission from the IMF's Statistics Department (STA) visited Amman during December 17-21, 2003 to update the data module of the Report on the Observance of Standards and Codes (ROSC) prepared by the February 2002 mission. The main objectives of this mission were to (i) review and document the actions undertaken by the authorities to address the issues raised by the 2002 data ROSC mission for national accounts, price, government finance, monetary, and balance of payments (BOP) statistics; and (ii) discuss the authorities' plans for further improving the quality of the statistics. A Special Data Dissemination Standard (SDDS) mission visited Amman during October 29-

November 8, 2006 to assess data dissemination practices against the requirements of the SDDS and assist preparations for subscription to the SDDS. Jordan is a participant in the General Data Dissemination System (GDDS), and its metadata were initially posted on the IMF's Dissemination Standards Bulletin Board (DSBB) in September 2000. Financial sector metadata (except for the stock market category) were last updated in December 2003. A national accounts statistics technical assistance mission visited Amman during December 10-21, 2006 to assist the department of statistics (DOS) with their project to develop the Supply and Use Tables (SUT).

3. Real sector. During the past two years, progress has been made toward enhancing the quality of national accounts statistics. However, the implementation of plans for improvement will require a strong commitment and allocation of additional resources. The main actions taken by the DOS in the area of national accounts statistics, since the 2002 ROSC mission, include:

- $\quad$ compilation of import-export price indices for the calculation of GDP at constant prices;

- $\quad$ estimation of household final consumption expenditure based on the 2002 Household Expenditure and Income Survey (HEIS);

- $\quad$ updating of supply and use of tables for the assessment and valuation of the statistical output;

- $\quad$ preparation of a study on the revision to the GDP series for 1976-2002;

- $\quad$ conducting workshops to enhance quality awareness of data providers and users, and to monitor user needs; 
- $\quad$ adoption of a comprehensive training program for national accounts statistics compilers; and

- dissemination of national accounts data at the two-digit level of the international standard industrial classification of economic activities.

4. With respect to price statistics, even though the CPI and PPI were already considered of good quality by the 2002 data ROSC mission, the DOS has short-term plans for improvements leading to full observance of international best practices. These plans include:

- $\quad$ incorporation of owner-occupied dwelling services in the CPI;

- $\quad$ updating of CPI weights based on the 2002 HEIS;

- $\quad$ dissemination of regional CPIs; and

- $\quad$ creation of core inflation.

5. With respect to the serviceability and accessibility of national accounts and price statistics, the DOS has short-term plans to:

- $\quad$ inform the public about the planning minister's access to data prior to public release (the ministry of planning has oversight responsibilities over the DOS);

- $\quad$ continue the program to increase quality awareness and monitor user needs;

- $\quad$ disseminate a statement on revision policy and practices in the DOS publications and website;

- disseminate an advance calendar for the release of national accounts and price statistics; and

- $\quad$ update the GDDS metadata on a more timely basis.

6. Government finance. An STA technical assistance mission visited Amman in April 2004 and found significant improvements in government finance statistics since the 2002 data ROSC mission. These improvements have been facilitated by the establishment of a statistical division in the ministry of finance (MOF) and the adoption of the Financial Management Reform Project (FMRP). The FMRP is guided by an interministerial committee headed by the secretary general of the MOF. Important actions that have already been taken include: 
- the regular publication of data on the operations of the consolidated general government; and

- $\quad$ initiation of migration to the methodology of the Government Finance Statistics Manual 2001 (GFSM 2001) — the authorities provide data in GFSM 2001 format for publication in the Government Finance Statistics Yearbook. The scope of these data is, however, limited to the operations of the central government budget and should be expanded.

7. Some of the actions contemplated in the comprehensive plan to improve the quality of government finance statistics include:

- dissemination of data on central and general government operations based on the classification and sectorization systems recommended by the GFSM 2001;

- $\quad$ seeking feedback from users of government finance statistics to monitor their needs;

- $\quad$ establishment of regular procedures for the verification of internal and intersectoral consistency of government finance statistics;

- dissemination of a statement on the revision policy, an advance release calendar, and more detailed metadata in the MOF publications and website; and

- $\quad$ updating of GDDS metadata on a more timely basis.

8. Monetary statistics. Monetary data for the Central Band of Jordan (CBJ) and the commercial banks are reported and published on a monthly basis. At present, consistency checks between government finance statistics and monetary statistics are not conducted. However, the CBJ authorities informed the 2003 ROSC update mission that the CBJ Research Department, which is responsible for the collection and compilation of the monetary statistics, proposed the establishment of an interagency group to monitor the intersectoral consistency of macroeconomic statistics. Further, actions are being taken to improve the quality of the source data and the methodological soundness of the statistical output. In particular, the $\mathrm{CBJ}$ is:

- $\quad$ reviewing a new set of report forms for banking institutions, which the Banking Supervision Department prepared to facilitate better classification and sectorization of the analytical accounts; and

- $\quad$ promoting the adoption of international accounting standards (IAS) by the commercial banks. Also, the Administrative and Financial Department and the Banking Supervision Department of the CBJ are in the process of adopting the IAS, 
in particular, with respect to valuation procedures and the recording of financial derivatives within the balance sheet.

Nevertheless, the reporting of monetary data for publication in International Financial Statistics remains irregular and little progress has been achieved so far by the CBJ in implementing the Standardized Report Forms for reporting monetary data to the Fund.

- Balance of payments (BOP) statistics. The establishment of a BOP division within the Research Department of the CBJ and the allocation of additional resources have facilitated the development of a comprehensive program for the improvement of BOP statistics, including a detailed action plan to address weaknesses in all data quality dimensions. These efforts were supported by long-term STA technical assistance involving two peripatetic missions. The CBJ has adopted the methodology of the fifth edition of the Balance of Payments Manual (BPM5) for the compilation of the BOP statistics and the international investment position (IIP), and has disseminated data in the BPM5 format. Further, the CBJ started compiling and disseminating the reserves template on the CBJ's website. The template has been reviewed by STA, and some minor outstanding issues will be addressed by an upcoming mission. The implementation of surveys in the area of services is important for the further improvement of the quality of the BOP statistics. Middle East Technical Assistance Center (METAC) provided technical assistance to the DOS in March 2005 on the construction of a foreign direct investment (FDI) survey. In October 2006, METAC also conducted an SDDS assessment mission. Preliminary results of the FDI survey containing data for 2004 and 2005 were presented by the DOS, the Investment Promotion Board, and the CBJ at a press conference on May 22, 2007. Efforts are continuing to complete the coverage of the IIP, including portfolio investment liabilities and private external debt. 


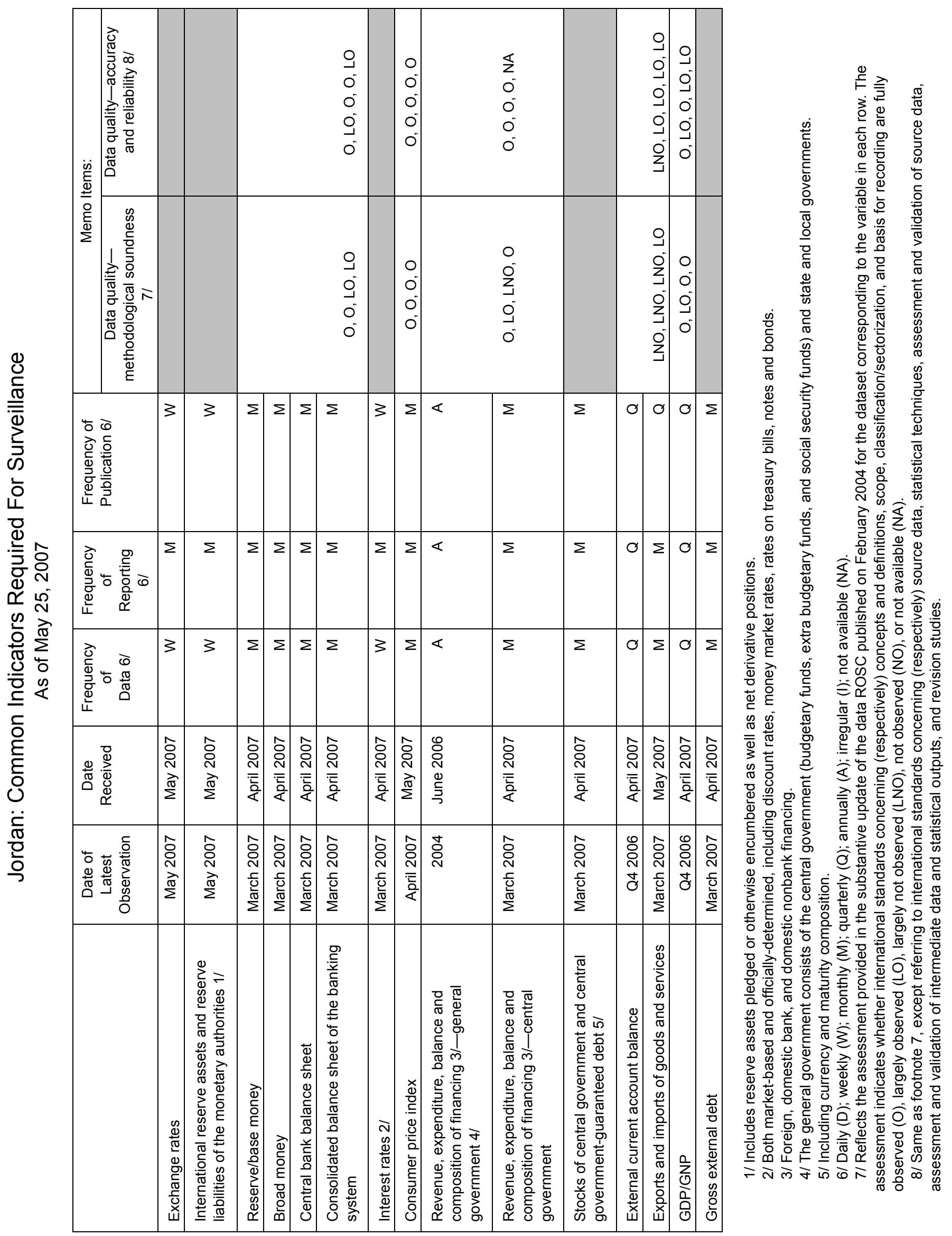




\section{APPENDIX II: RELATIONS WITH THE FUND}

(As of April 30, 2007)

I. Membership Status: Joined: August 29, 1952; Article VIII

II. General Resources Account:

Quota

Fund holdings of currency

Reserve position in Fund

III. SDR Department:

Net cumulative allocation

Holdings

IV. Outstanding Purchases and Loans:

Extended Arrangements

$\begin{array}{cc}\text { SDR million } & \text { \% Quota } \\ 170.50 & 100.00 \\ 252.09 & 147.85 \\ 0.23 & 0.14\end{array}$

SDR million \% Allocation

16.89

100.00

3.24

19.16

SDR million

81.80
\% Quota

47.98

V. Latest Financial Arrangements:

\begin{tabular}{|c|c|c|c|c|}
\hline Type & $\begin{array}{c}\text { Approval } \\
\text { Date }\end{array}$ & $\begin{array}{c}\text { Expiration } \\
\text { Date }\end{array}$ & $\begin{array}{c}\text { Amount Approved } \\
\text { (SDR million) }\end{array}$ & $\begin{array}{c}\text { Amount Drawn } \\
\text { (SDR million) }\end{array}$ \\
\hline SBA & $7 / 03 / 02$ & $7 / 02 / 04$ & 85.28 & 10.66 \\
\hline EFF & $4 / 15 / 99$ & $5 / 31 / 02$ & 127.88 & 127.88 \\
\hline EFF & 2/09/96 & 2/08/99 & 238.04 & 202.52 \\
\hline
\end{tabular}

VI. Projected Obligations to Fund (Expectations Basis): (SDR million; based on existing use of resources and present holdings of SDRs)

\begin{tabular}{lrrrrr} 
& \multicolumn{5}{c}{ Forthcoming } \\
\cline { 2 - 6 } & \multicolumn{1}{c}{2007} & \multicolumn{1}{c}{2008} & 2009 & 2010 & 2011 \\
\cline { 2 - 6 } Principal & 26.39 & 37.52 & 15.35 & 2.54 & \\
Charges/Interest & 3.85 & 2.96 & 1.15 & 0.65 & 0.58 \\
Total & $\underline{30.24}$ & $\underline{40.49}$ & $\underline{16.50}$ & $\underline{3.18}$ & $\underline{0.58}$
\end{tabular}

VII. Safeguards Assessment: Under the Fund's safeguards assessment policy, the CBJ was subject to a full assessment with respect to the Stand-By Arrangement (SBA), which was approved on July 3, 2002 and expired on July 2, 2004. The assessment was completed on June 27, 2003, and concluded that the CBJ has made progress in strengthening its safeguards, as recommended in the previous assessment of May 2001. The assessment proposed a set of measures, the majority of which have been implemented. Implementation of the remaining recommendations is being monitored by staff. 
VIII. Exchange System: The Jordanian dinar is fully convertible and is officially pegged to the SDR. In practice, the authorities have tightly linked its exchange rate to the U.S. dollar since October 1995, at JD $1=\$ 1.41044$.

IX. Article IV Consultation: The 2006 Article IV consultation was concluded by the Executive Board on March 5, 2007. Two Financial Sector Assessment Program missions visited Jordan in August and September 2003, and the Financial System Stability Assessment (FSSA) was published in January 2004. The Ex Post Assessment (EPA) of Jordan's of Longer-Term Program Engagement was published in November 2005.

X. Technical Assistance: Extensive technical assistance has been provided to Jordan over the years (Table A.3).

\section{Documents:}

Standards or Codes Assessed

Data module

FSSA

Update to data module

Fiscal transparency module
Date of Issuance

$10 / 8 / 2002$

$1 / 7 / 2004$

$1 / 30 / 2004$

$1 / 9 / 2006$ 
Table A.3. Technical Assistance, 1999-2007

\begin{tabular}{|c|c|}
\hline Date & Purpose \\
\hline \multicolumn{2}{|l|}{ Fiscal } \\
\hline August 1999 & Income tax reform \\
\hline March 2000 & Pension reform \\
\hline May 2000 & Framework for managing nontreasury accounts \\
\hline September 2000 & Oil pricing mechanism \\
\hline January-June 2002 & Pension reform \\
\hline January-September 2002 & GST reform \\
\hline November 2002 & Macrofiscal capacity and treasury single account \\
\hline February, October 2003 & Revenue administration reform \\
\hline June, August, December 2003 & Peripatetic advisor on single treasury account \\
\hline February, June, October 2004 & Peripatetic advisor on revenue administration reform \\
\hline February, May 2004 & Public expenditure management \\
\hline August 2004-June 2005 & Resident expert in macrofiscal management \\
\hline February 2005 & Distributional effects of replacing oil subsidies \\
\hline February-March 2005 & Revenue administration reform \\
\hline April 2005 & Fiscal ROSC \\
\hline February, May 2006 & Public financial management \\
\hline April-August 2006 & Expert visits on revenue administration reform \\
\hline October-November 2006 & Revenue administration inspection visit \\
\hline \multicolumn{2}{|l|}{ Monetary and Financial } \\
\hline August 1999 & Auctions of government securities, and auditing and accounting reform \\
\hline August 1999-August 2000 & Resident expert in banking supervision \\
\hline September 1999-September 2000 & Resident expert in payment system development \\
\hline December 1999 & Development of the domestic and foreign exchange interbank market \\
\hline January-February, April-May 2001 & International reserve management \\
\hline \multicolumn{2}{|l|}{ Statistical } \\
\hline February 1999 & Preparation of General Data Dissemination System (GDDS) metadata \\
\hline April 1999 & Revision of the PPI sample and PPI calculation \\
\hline September 1999 & National accounts statistics \\
\hline November 1999 & PPI statistics \\
\hline July 2000 & National accounts statistics \\
\hline January-February 2002 & Report on the Observation of Standards and Codes_-Data module \\
\hline December 2003 & $\begin{array}{l}\text { Follow-up on Report on the Observation of Standards and Codes-Data } \\
\text { module }\end{array}$ \\
\hline Oct. 2003-Jan. 2004, Mar-May 2004 & Balance of payments statistics \\
\hline April-May 2004 & Government finance statistics \\
\hline
\end{tabular}




\section{APPENDIX III: WORLD BANK GROUP STRATEGY AND OPERATIONS}

9. As of April 30, 2007, Jordan had received 68 World Bank (Bank) loans, 2 guarantees, and 15 IDA credits totaling $\$ 2,225$ million net of cancellations and terminations. Of the $\$ 2,346$ million, $\$ 2,126$ million have been disbursed to-date. All the credits and 61 of the loans have been fully disbursed. There are seven active projects in the Bank's portfolio for a total of $\$ 280$ million. Overall performance of the portfolio is good, both from the perspective of implementation and development impact. This reflects the generally good project implementation capacity of Jordanian institutions, Jordan's strong ownership of the program, and the quality of the dialogue between the Bank and the government of Jordan. The International Finance Corporation (IFC) has made cumulative loan and equity investment commitments of \$279 million and about \$70 million in syndications as of April 30, 2007.

10. The new Joint World Bank-IFC country assistance strategy (CAS) for 2006-10, endorsed by the Bank's Executive Board in May 2006, is aligned with the government priorities, as expressed in particular in the 10-year National Agenda, of poverty alleviation and the creation of higher productivity jobs, while assisting the country in its transition through the medium-term economic shocks. This CAS sets out a four-year program organized in four cross-sectoral clusters:

- strengthening the investment environment and building human resources for value-added, skill-intensive, and knowledge-based economy;

- supporting local development through increased access to services and economic opportunities;

- reforming social assistance and expanding inclusion; and

- restructuring public expenditures and supporting public sector reform.

11. The first two clusters tackle issues related to private investment and job creation, respectively at the macro level and at the local level. The third cluster deals with programs to support those who cannot by themselves achieve sufficient welfare. The last cluster is focused on strengthening the public administration's ability to design and implement development polices, including improvements in the government budget, as the main tools of public policy. Important cross-cutting issues, such as gender and the environment, will be mainstreamed into the clusters. Various sectoral concerns, such as water and energy, will be integrated in these programmatic clusters through thematic approach. The CAS mix among possible policy lending, investment lending, and analytical services reflects the emerging needs with respect to short-term financial challenges and longer-term institutional developments, with a lending ceiling of up to US\$540 million over four years.

12. Two investment loans were approved this fiscal year aiming to assist Jordan achieve a regionally balanced and equitable growth including access to services, employment 
opportunities, and private investments outside Amman. One partial risk guarantee for the Amman East 370 MW power plant was also approved this FY.

13. World Bank Group support to private sector development will continue to focus on improving the investment environment, public private partnership, partial risk guarantees for major projects (envisaged to attract private sector participation and to provide a better financial package for critical projects in water and energy), and, in the case of IFC, direct investment. The IFC has been active in Jordan for many years and has a current portfolio of $\$ 41$ million in eleven companies as of April 30, 2007. IFC places a high priority on business development to seek investment opportunities in the following areas: (i) infrastructure development to encourage foreign direct investment; (ii) financial sector development (e.g., microfinance and trade finance); and (iii) export-oriented and foreign exchange generating investments. The IFC's advisory activities in Jordan intend to fill the gaps and address critical areas for private sector development, such as improving the investment climate. 
August 10, 2007

\section{IMF Executive Board Concludes Fifth Post-Program Monitoring Discussions with Jordan}

On June 25, 2007 the Executive Board of the International Monetary Fund (IMF) concluded the Fifth Post-Program Monitoring Discussions with Jordan on a lapse-of-time basis.

Jordan graduated from a series of Fund-supported programs in 2004 and has since been engaged in post-program monitoring, which expires at the end of 2007. The Fifth Post-Program Monitoring Discussions with the Jordanian authorities were held in April 2007 (Jordan: Fifth Post-Program Monitoring Discussions-Staff Report). 